
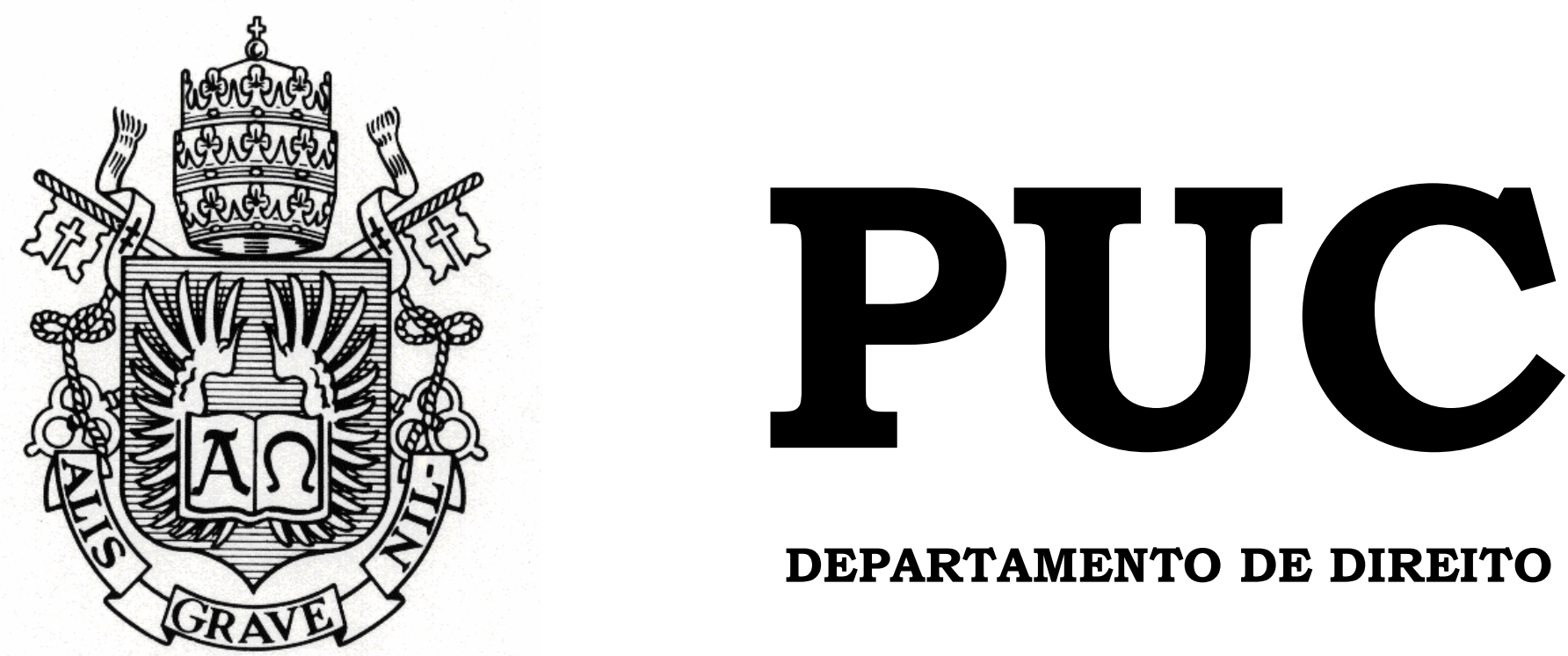

DEPARTAMENTO DE DIREITO

\title{
Alienação fiduciária em garantia de bem imóvel: uma análise do instituto
}

por

Fabiana Peixoto Siccardi

ORIENTADOR(A): Daniela Trejos Vargas

2008.1

PONTIFÍCIA UNIVERSIDADE CATÓLICA DO RIO DE JANEIRO

RUA MARQUÊS DE SÃO VICENTE, 225 - CEP 22453-900

RIO DE JANEIRO - BRASIL 


\section{Alienação fiduciária em garantia de bem imóvel: uma análise do instituto}

por

\section{Fabiana Peixoto Siccardi}

Monografia apresentada ao Departamento de Direito da Pontificia Universidade Católica do Rio de Janeiro (PUC-Rio) para a obtenção do Título de Bacharel em Direito.

Orientador(a): Daniela Trejos Vargas 


\section{Dedicatória}

Aos meus pais e a meu irmão por tudo. 


\section{Agradecimentos}

Agradeço a Deus, à minha família pelo amor, paciência, compreensão, torcida e incentivo; aos meus amigos, além da fiel amizade, pela compreensão de que as aulas aos sábados eram obrigatórias; aos meus amigos da PUC por estes cinco anos maravilhosos; à professora Daniela Vargas pela dedicação e orientação impecáveis; aos demais professores pela contribuição à minha formação acadêmica e à elaboração desta monografia; aos funcionários do Departamento de Direito pelo constante auxílio; às pessoas com que estagiei pelo aprendizado prático, enfim, a todos que ao longo destes cinco anos cruzaram meu caminho e participaram do meu crescimento pessoal e acadêmico. 
"Creditors have better memories than debtors." (Benjamin Franklin, Poor Richard's Almanac, 1758)

"O crédito é, pois, o modo de produção mais perigoso que vimos até agora, e só presta serviços nas sociedades cuja educação econômica está muito adiantada". (Charles Guide, Compêndio de Economia) 


\section{Resumo}

O presente trabalho objetiva abordar o instituto da alienação fiduciária em garantia de bem imóvel da Lei $\mathrm{n}^{0} 9.514$ de 1997, seus requisitos, extinção, venda no público leilão e suas conseqüências, bem como a análise da propriedade fiduciária imobiliária. Segundo a legislação pátria, o procedimento para a retomada do bem pelo credor é mais célere, o que diferencia o mencionado direito real de garantia dos demais. Devido a essa celeridade, inúmeros devedores questionam o procedimento supracitado, angustiando-se com a consolidação da propriedade plena favorecendo o credor, assim como, a inaplicabilidade do artigo 53 do Código de Defesa do Consumidor.

Assim, são as palavras-chave para leitura que se segue: sistema de financiamento imobiliário, crédito, garantia, alienação fiduciária em garantia de bem imóvel, propriedade fiduciária imobiliária, público leilão, pacto comissório e decaimento das parcelas pagas. 


\section{Sumário}

$\begin{array}{ll}\text { Introdução } & 07\end{array}$

1. Crédito e Garantias $\quad 10$

$\begin{array}{ll}1.1 \text { Crédito } & 10\end{array}$

1.2Garantias 12

2. Alienação Fiduciária de Imóvel 21

2.1 Histórico 21

$\begin{array}{ll}2.2 \text { Instituto } & 26\end{array}$

2.2.1 Propriedade Fiduciária Imobiliária 28

2.2.2 Requisitos 33

2.2.2.1 Requisitos Subjetivos 33

2.2.2.1.1 Cessão da posição do fiduciário 36

2.2.2.1.2 Cessão da posição do fiduciante $\quad 39$

2.2.2.2 Requisitos Objetivos 40

2.2.2.3 Requisitos Formais 43

2.2.2.3.1 Cláusulas Essenciais $\quad 43$

2.2.2.2 Requisitos de Forma 48

2.2.3 Extinção do contrato $\quad 50$

2.2.3.1 Pelo adimplemento do fiduciante $\quad 50$

2.2.3.2 Pelo inadimplemento do fiduciante 53

2.2.4 Leilão

3. Aspectos interessantes sobre a consolidação da propriedade plena 66

3.1 Pacto comissório 66

3.2 Perda das parcelas pagas e o artigo 53 do Código de Defesa $\begin{array}{ll}\text { do Consumidor } & 67\end{array}$

$\begin{array}{ll}\text { Conclusão } & 74\end{array}$

$\begin{array}{ll}\text { Referências bibliográficas } & 78\end{array}$ 


\section{Introdução}

Com o advento da Lei $\mathrm{n}^{0} 9.514$ de 1997, foi criado o Sistema de Financiamento Imobiliário e a alienação fiduciária em garantia de bem imóvel. Esta lei é reconhecidamente importante, pois facilita o acesso da população ao crédito para compra de imóvel, tendo em vista que reduz o risco do credor. Constitui em favor do credor uma propriedade resolúvel sobre o imóvel dado pelo devedor a fim de garantir uma outra obrigação, comumente, um empréstimo.

A alienação fiduciária de bens imóveis é utilizada cotidianamente em todo o país, contribuindo para a expansão do crédito imobiliário. Dessa forma, são recorrentes as matérias jornalísticas sobre o assunto. A título de ilustração:

Mas a principal inovação do SFI foi a chamada alienação fiduciária, forma de garantia do empréstimo em que o imóvel fica em nome do banco e não do comprador. Isso facilita a possibilidade de venda do imóvel em caso de pagamento da dívida, ou seja, reduz o risco do banco na operação. Criada para o SFI, a alienação fiduciária passou a ser adotada também nos contratos do $\mathrm{SFH}$, em substituição à hipoteca do imóvel. ${ }^{1}$

Em seguida, destaca-se trecho de notícia acerca da expansão do crédito:

Segundo dados do Banco Central, as operações de crédito representam atualmente cerca de 33 por cento do Produto Interno Bruto brasileiro. (...) O crédito imobiliário está entre as apostas de bancos para o ano que vem, à medida que os juros caem e os brasileiros demonstram mais disposição em assumir compromissos mais longos. ${ }^{2}$

Nesse sentido, tendo em vista a popularidade da alienação fiduciária instituída pela lei supracitada pela novidade da propriedade fiduciária

\footnotetext{
${ }^{1}$ PAULA, Nice de. Estabilidade e mudança nas regras trouxeram mais recursos ao setor. Disponível em http://oglobo.globo.com/economia/mat/2005/08/24/169575275.asp. Acesso em 20 de novembro de 2007.

${ }^{2}$ SIQUEIRA, Juliana. Expansão de crédito em 2007 supera estimativas do Itaú. Disponível em http://oglobo.globo.com/economia/mat/2007/11/06/327051496.asp . Acesso em 20 de novembro de 2007.
} 
imobiliária, o presente trabalho busca fazer um panorama sobre o contrato, delineando as características do inaugurado direito real em garantia, aclarar o procedimento previsto legalmente a ser promovido pelo credor para satisfação do crédito, bem como as consequiências dele decorrentes. Dentre as quais, serão examinadas a consolidação da propriedade em favor do credor nas hipóteses de venda frustrada em leilão e a aplicabilidade do artigo 53 do Código de Defesa do Consumidor neste tipo de contrato.

Desde já, alerta-se que, por diversas vezes, o procedimento legal indicado foi questionado judicialmente justamente por tornar o processo de execução mais célere e por prever a consolidação da propriedade plena em nome do credor em determinados casos. No entanto, é em razão desta celeridade e segurança que este contrato tornou-se popular, atendendo os anseios de ambas as partes da relação contratual, pois, é certo que o devedor é favorecido na execução desta garantia quando comparado à execução de outras garantias.

Nessa trilha, fechar os olhos aos questionamentos relativos à alienação fiduciária de imóveis e ao seu procedimento legal de execução é ignorar sua existência no dia-a-dia de milhares de brasileiros. Assim sendo, busca-se, ao fim do presente trabalho, esclarecer certas questões, quais sejam, as relativas à configuração da propriedade fiduciária imobiliária, ao delineamento da alienação fiduciária em garantia de bens imóveis e a aspectos interessantes da excussão da garantia e da consolidação da propriedade plena para o credor.

Nessa linha, para que o tema escolhido seja devidamente estudado, analisa-se o crédito e as características das garantias reais pátrias no capítulo 1, a alienação fiduciária em garantia de bem imóvel, detalhando seu histórico, características da propriedade fiduciária imobiliária, requisitos do contrato de alienação fiduciária de bens imóveis, extinção do contrato, o leilão previsto na Lei $\mathrm{n}^{0} 9.514$ de 1997 no capítulo 2; os aspectos interessantes sobre a consolidação da propriedade plena no capítulo 3, culminando, finalmente, na conclusão. 
Já em relação ao material levantado para a elaboração desta monografia, optou-se pela escolha de várias fontes de consulta, destacam-se os exames da legislação pertinente, da doutrina de direito civil e de títulos de crédito, bem como das matérias jornalísticas e da jurisprudência. 


\section{Crédito e Garantias}

\section{$1.1 \quad$ Crédito}

Crédito é a concessão de recursos de uma pessoa (credor) à outra (devedor), em que fica acordado que a devolução dos recursos ou de sua quantia equivalente não ocorrerá imediatamente, mas sim em um momento

futuro. É para Stuart Mill a permissão para usar capital alheio. A acepção jurídica do termo significa o direito à prestação do devedor ${ }^{3}$.

Destaca-se que o crédito não cria riqueza, não é agente de produção, mas sim possibilita a troca de bens presentes por bens futuros, fomentando dessa forma a atividade econômica. É importante instrumento de mobilização da riqueza, permitindo a otimização do uso dos capitais existentes. Evita que enorme massa de capitais fique sem emprego. ${ }^{4} \mathrm{Nas}$ palavras de Charles Guide:

(...) não faltam, no mundo, pessoas empreendedoras, inventoras, agricultoras e até obreiras, que sabem tirar partido dos capitais quando lhes toca a felicidade de os ter. Pois, graças ao crédito, é que os capitais chegam a passar às mãos daqueles que estão no caso de os empregar produtivamente, para maior proveito de cada um deles, e do país inteiro. Ora, é aos milhões que se computam em todos os países os capitais assim subtraídos quer pelo entesouramento estéril, quer pelo consumo improdutivo, mas fecundados pelo crédito. Já se disse com razão que o crédito tinha a virtude de fazer passar ao estado ativo os capitais que se conservam em estado latente. Em suma, o crédito desempenha relativamente aos capitais o mesmo papel que a troca relativamente às riquezas. Já vimos que a troca, transferindo-as de um produtor a outro, não as cria, mas serve para utilizá-las melhor e para melhor utilizar o trabalho dos produtores e as riquezas naturais. ${ }^{5}$

Nesse sentido, a circularização do crédito fornece poder de compra a quem não possui meios próprios para tal. É através do crédito que milhares de brasileiros adquirem eletrodomésticos, automóveis e imóveis, elevando

\footnotetext{
${ }^{3}$ Segundo Waldirio Bulgarelli, em sua obra Títulos de crédito, o credito do ponto de vista jurídico, embora não contrarie as acepções moral e econômica, tem conceito preciso e próprio. (BULGARELLI, Waldirio. Títulos de Crédito. $16^{\mathrm{a}}$ ed. São Paulo: Atlas, 2000. p. 20.).

${ }^{4}$ GUIDE, Charles. Compêndio d'Economia Política, apud BULGARELLI, Waldirio. Títulos de Crédito, p. 19.

${ }^{5}$ GUIDE, Charles. Compêndio d'Economia Política, apud BULGARELLI, Waldirio. Títulos de Crédito, p. 19.
} 
os índices de consumo, bem como industriais investem no aumento e aperfeiçoamento da produção para atender à exigente demanda dos consumidores.

Retornando ao conceito de crédito, pode-se observar que é composto por dois elementos: o tempo e a confiança.

O tempo não traz qualquer dificuldade de compreensão, pois o crédito pressupõe prazo. Há sempre lapso temporal entre a concessão de recurso pelo credor e o pagamento pelo devedor. Conforme foi dito, sendo o crédito a troca de bens presentes por futuros, não haveria sentido o pagamento logo após a concessão.

Quanto ao segundo elemento, a confiança ${ }^{6}$, traduz-se na crença do credor no adimplemento do devedor em relação à obrigação pactuada. Segundo ensina o jurista Luiz Emygdio F. da Rosa Jr., a confiança deve ser analisada sob dois aspectos: o subjetivo e o objetivo.

O elemento subjetivo consiste na crença que o credor deposita na pessoa do devedor de que preenche os requisitos morais básicos necessários à efetivação do negócio de crédito, ou seja, que o devedor aplicará a sua capacidade econômica no cumprimento de sua obrigação, correspondente ao pagamento do empréstimo no prazo fixado. O elemento objetivo da confiança compreende a certeza que o credor tem de que o devedor possui capacidade econômico-financeira para lhe restituir a importância mutuada no termo final do prazo, resultando essa confiança do conhecimento da renda e do patrimônio do devedor. ${ }^{7}$

Apesar do acima exposto, há quem pense que a confiança não mais integra o conceito de crédito, tendo em vista que é prática corrente das instituições financeiras exigir algum tipo de garantia do devedor. $\mathrm{Na}$ verdade, a confiança continua a fazer parte do conceito supracitado. A exigência de garantia não veio para tomar-lhe lugar, mas sim para resguardar o credor face ao inadimplemento do devedor.

Risco é a possibilidade de perda e de ganho, em igualdade de condições e conforme atendidas regras determinadas. Funcionam os

\footnotetext{
${ }^{6}$ Pela etimologia da palavra, crédito deriva de creditum (credere), significando crença, confiança. Assim, esta é a acepção moral de crédito.

${ }^{7}$ ROSA JUNIOR, Luiz Emygdio Franco da. Títulos de Crédito, $4^{\mathrm{a}}$ ed. Rio de Janeiro: Renovar, 2006. p. 3.
} 
contratos como instrumentos de redução de risco e de criação de situações eficientes. São as palavras de Armando Castelar Pinheiro e Jairo Saddi:

Risco é alea, (...) é lançar-se sobre o desconhecido. Todos os agentes econômicos no mercado estarão sempre exercendo suas atividades econômicas com o fito de obter lucros e, em face disso, correm os correspondentes riscos. (...).

A incerteza, ou o risco, dependendo do caso, também afeta diretamente a "performance" do contrato. (...) o risco existe e a forma de mitigá-lo (ou reduzi-lo) é celebrar um contrato em que se estimam condições e situações que possam ocorrer no seu cumprimento. $O$ contrato desempenha, assim, uma função econômica: reduzir e, principalmente, alocar e distribuir riscos entre as partes ${ }^{8}$.

Nesse sentido, é procedimento das financeiras nas inúmeras operações de crédito que são realizadas diariamente, a inclusão de garantias, a fim de mitigar a chance de prejuízo e tornar mais célere a recuperação do crédito.

\section{$1.2 \quad$ Garantia}

A garantia é o meio jurídico que, na relação obrigacional, protege o direito subjetivo de uma das partes, assegurando ou acautelando esse direito contra qualquer lesão resultante da inexecução da obrigação pelo devedor ${ }^{9}$. Comporta duas espécies: pessoal e real.

A garantia pessoal, também chamada de fidejussória, é aquela em que um terceiro se responsabiliza pela satisfação da obrigação caso o devedor não a cumpra. É o patrimônio do terceiro, no estado em que se encontra na época da execução, que responderá pela dívida. Dessa forma, é chamada de garantia relativa, pois o terceiro pode ser insolvente no momento da execução da sua obrigação. Incluem-se nesta espécie de garantia a fiança e o aval.

Já a garantia real é mais eficaz que a pessoal, uma vez que vincula um bem do devedor ao pagamento da dívida com faculdade de

\footnotetext{
${ }^{8}$ PINHEIRO \& SADDI. Direito, Economia e Mercados. Rio de Janeiro: Elsevier, 2005. pp. $121 \mathrm{e}$ 122.

${ }^{9}$ ROSA JUNIOR, Luiz Emygdio Franco da. Títulos de Crédito, p. 3.
} 
oponibilidade erga omnes. Segundo os ensinamentos de Caio Mário da Silva Pereira, "na essência, a garantia real consiste na realização do valor da coisa, isto é em obter certa soma de dinheiro mediante sua alienação"10. No mesmo sentido, leciona Orlando Gomes que

direito real de garantia é o que confere ao credor a pretensão de obter o pagamento da dívida com o valor do bem aplicado exclusivamente à sua satisfação. Sua função é garantir ao credor o recebimento da dívida, por estar vinculado determinado bem ao seu pagamento. $\mathrm{O}$ direito do credor concentra-se sobre determinado elemento patrimonial do devedor. Os atributos de seqüela e preferência atestam sua natureza substantiva e real. ${ }^{11}$

Pode-se observar, portanto, que nos direitos reais de garantia, figura entre o proprietário e a coisa um outro sujeito de direito a exercer faculdades sobre o bem, afastando a plenitude do direito real de propriedade do proprietário e limitando o exercício de suas faculdades.

São espécies de garantias reais previstas em nosso direito: o penhor, a hipoteca, a anticrese e a propriedade fiduciária.

Os direitos reais de garantia são regidos pelos seguintes princípios: tipicidade, especialidade, publicidade e indivisibilidade.

A tipicidade significa que não há autonomia da vontade para criação de um tipo de garantia, visto que as mesmas são previstas em lei de forma taxativa. A autonomia da vontade restringe-se à contratação. É o sistema do numerus clausus. Conforme leciona San Tiago Dantas,

a razão para a vontade das partes estar impedida de criar os mencionados direitos é "porque sendo certo que os direitos reais prevalecem erga omnes, seria inadmissível que duas, três ou mais pessoas pudessem, pelo acordo de suas vontades criar deveres jurídicos para toda a sociedade ${ }^{12}$.

Já a especialidade consiste na identificação do bem objeto da garantia de acordo com os artigos 1.424 e 1.362 do Código Civil.

\footnotetext{
${ }^{10}$ PEREIRA, Caio Mário da Silva. Instituições de Direito Civil - volume IV. $18^{\mathrm{a}}$ ed. Rio de Janeiro: Forense, 2004. p. 324.

11 GOMES, Orlando. Direitos Reais, apud GONÇALVES, Carlos Roberto. Direito Civil Brasileiro - volume V. São Paulo: Saraiva, 2004. p. 491.

${ }_{12}$ DANTAS, San Tiago. Programma, apud GONÇALVES, Carlos Roberto. Direito Civil Brasileiro - volume V, p. 17.
} 
Art. 1.424. Os contratos de penhor, anticrese ou hipoteca declararão, sob pena de não terem eficácia:

IV - o bem dado em garantia com as suas especificações; e

Art. 1.362. O contrato, que serve de título à propriedade fiduciária, conterá:

IV - a descrição da coisa objeto da transferência, com os elementos indispensáveis à sua identificação.

Justifica-se a identificação, pois como mencionado anteriormente, a garantia real recai sobre um bem do patrimônio do devedor, enquanto a garantia pessoal recai sobre a sua totalidade. Assim, faz-se necessária a identificação do bem onerado, pois deixa de ser garantia de todos os credores, passando a ser de um só. Opera como garantia de terceiros, permitindo que avaliem a real situação patrimonial do devedor antes de realizarem algum negócio jurídico com o mesmo.

No tocante à publicidade, é, para Arruda Alvim, "condição de operabilidade do princípio do absolutismo. Os direitos reais só se podem exercer contra todos se forem ostentados publicamente"13. Dessa forma, a garantia real só é oponível a terceiros se levada ao registro competente sob pena de ineficácia ${ }^{14}$. É competente o Registro Geral de Imóveis se o bem gravado for imóvel (artigo 1.227 do Código Civil) e o Cartório de Títulos e Documentos se a garantia recair sobre bem móvel (artigo 1.432 do Código Civil).

Em especial, o registro da garantia sobre bem móvel visa caracterizar a natureza verdadeira da tradição, evitando que esta seja percebida como transferência de propriedade, visto que se sabe que a posse é a forma de publicizar o domínio sobre bem móvel.

\footnotetext{
13 ALVIM, Arruda, Breves anotações, apud GONÇALVES, Carlos Roberto. Direito Civil Brasileiro - volume V, p. 14.

${ }^{14}$ Corroboram Cristiano Chaves de Farias e Nelson Rosenvald ao ensinarem que "seja qual for a modalidade de direito de garantia, qualquer pessoa que venha a estabelecer relações jurídicas com o devedor só poderá responsabilizar-se perante o titular do direito real caso tenha conhecimento das restrições patrimoniais inseridas no registro. Realmente, não há oponibilidade erga omnes, sem a correlata publicidade". (FARIAS, Cristiano Chaves; ROSENVALD, Nelson. Direitos Reais. $3^{\mathrm{a}}$ ed. Rio de Janeiro: Lumen Júris, 2006. p. 617).
} 
Por fim, a indivisibilidade é a impossibilidade de redução da garantia com o pagamento de parcelas da dívida, conforme observância do artigo $1.421^{15}$ do Código Civil.

Justifica-se a impossibilidade de liberação da garantia na proporção do pagamento efetuado, uma vez que a garantia adere ao bem gravado por inteiro e em cada uma de suas partes ${ }^{16}$. A indivisibilidade da obrigação decorre da própria razão determinante do negócio jurídico, e não do objeto em $\mathrm{si}^{17}$.

No entanto, ressalta Carlos Roberto Gonçalves que tem o devedor o direito de efetuar a remição. Todavia esta só liberará os bens em garantia se for total, porque pelo princípio da indivisibilidade, não se admite a remição parcial. Não obstante, tendo em vista a amortização da dívida, as partes podem acordar pela desoneração do bem para onerar outro de menor valor.

Além dos princípios das garantias reais, é necessário abordar também seus requisitos para constituição. São eles: subjetivo, objetivo e formal.

O requisito subjetivo estipula que somente pessoas capazes de acordo com a lei civil ${ }^{18}$ e com capacidade para alienar a coisa podem dar o bem em garantia. Segundo Caio Mário da Silva Pereira,

importando a constituição da garantia real em começo de disposição, pois que o bem já é destacado do patrimônio do devedor para assegurar a solutio, a lei requer, afora a capacidade genérica para os atos da vida

\footnotetext{
15 Art. 1.421. O pagamento de uma ou mais prestações da dívida não importa exoneração correspondente da garantia, ainda que esta compreenda vários bens, salvo disposição expressa no título ou na quitação.

${ }^{16}$ GONÇALVES, Carlos Roberto. Direito Civil Brasileiro - volume V, p. 504.

${ }^{17}$ FARIAS \& ROSENVALD. Direitos Reais, p. 614.

${ }^{18}$ Art. 3 São absolutamente incapazes de exercer pessoalmente os atos da vida civil:

I - os menores de dezesseis anos;

II - os que, por enfermidade ou deficiência mental, não tiverem o necessário discernimento para a prática desses atos;

III - os que, mesmo por causa transitória, não puderem exprimir sua vontade.

Art. 4 são incapazes, relativamente a certos atos, ou à maneira de os exercer:

I - os maiores de dezesseis e menores de dezoito anos;

II - os ébrios habituais, os viciados em tóxicos, e os que, por deficiência mental, tenham o discernimento reduzido;

III - os excepcionais, sem desenvolvimento mental completo;

IV - os pródigos;

Parágrafo único. A capacidade dos índios será regulada por legislação especial.
} 
civil, a especial para alienar. Particularizando, diz-se então que somente o proprietário pode dar bens em garantia real. Cumpre, entretanto, ressaltar que não basta ser proprietário, mas é mister que, além do domínio, tenha ainda a livre disposição da coisa. ${ }^{19}$

Assim, embora o menor seja proprietário, seus pais precisam de autorização judicial para dar seus bens em garantia (artigo 1.691 do Código Civill $^{20}$; o cônjuge precisa da outorga do outro cônjuge para constituição de qualquer ônus real (artigo 1.647, I do Código Civil.) ${ }^{21}$; o falido é impedido de constituir direito real de garantia (artigo 103 da Lei 11.101 de $09 / 02 / 2005)^{22}$, dentre outros exemplos.

No que tange ao requisito objetivo, vincula-se aos objetos passíveis de gravame real. Somente bens alienáveis podem ser dados em garantia, ou seja, bens passíveis de disposição. Nesse sentido, exemplifica Carlos Roberto Gonçalves que:

não podem ser objeto de garantia, sob pena de nulidade, os bens fora do comércio, como os públicos, os inalienáveis enquanto assim permanecerem, o bem de família, os imóveis financiados pelos Institutos e Caixas de Aposentadorias e Pensões (Dec.-Lei n. 8.618, de 10-1$1946)^{23}$.

Quanto ao requisito formal, a lei prescreve a observância de formalidades para a realização de contratos de garantia, pois tais contratos têm imensa repercussão social e, além disso, são o início da alienação. Nesse sentido, afirma Caio Mario da Silva Pereira,

tendo em vista a circunstância de promover a garantia um começo de alienação, e levada em conta a sua repercussão social, pois que destaca do patrimônio um bem que era garantia de todos os credores, para tornarse em segurança de um só, a lei não se contenta em que as partes livremente convencionem a sua constituição, mas impõe a observância de

\footnotetext{
${ }^{19}$ PEREIRA, Caio Mário da Silva. Instituições de Direito Civil - volume IV, p. 324.

20 Art. 1.691. Não podem os pais alienar, ou gravar de ônus real os imóveis dos filhos, nem contrair, em nome deles, obrigações que ultrapassem os limites da simples administração, salvo por necessidade ou evidente interesse da prole, mediante prévia autorização do juiz.

${ }^{21}$ Art. 1.647. Ressalvado o disposto no artigo 1.648, nenhum dos cônjuges pode, sem autorização do outro, exceto no regime da separação absoluta:

I - alienar ou gravar de ônus real os bens imóveis.

22 Art. 103. Desde a decretação da falência ou do seqüestro, o devedor perde o direito de administrar os seus bens ou deles dispor.

${ }^{23}$ GONÇALVES, Carlos Roberto. Direito Civil Brasileiro - volume V, p. 496.
} 
dadas formalidades, sem as quais os contratos (...) são inválidos perante terceiros. $^{24}$

Nessa trilha, dos contratos de garantia devem constar, de acordo com o artigo 1.424 do Código Civil.

Art. 1.424. Os contratos de penhor, anticrese ou hipoteca declararão, sob pena de não terem eficácia:

I - o valor do crédito, sua estimação, ou valor máximo;

II - o prazo fixado para pagamento;

III - a taxa dos juros, se houver;

IV - o bem dado em garantia com as suas especificações.

A respeito da propriedade fiduciária, devem constar do contrato as seguintes cláusulas:

Art. 1.362. O contrato, que serve de título à propriedade fiduciária, conterá:

I - o total da dívida, ou sua estimativa;

II - o prazo, ou a época do pagamento;

III - a taxa de juros, se houver;

IV - a descrição da coisa objeto da transferência, com os elementos indispensáveis à sua identificação.

No entanto, cumpre ressaltar que a ausência de um dos requisitos não fulmina o contrato por completo, mas sim apenas contra terceiros e não entre as partes. Entretanto, sendo ineficaz contra terceiros, o principal fim perseguido pelo credor ao buscar uma garantia real, isto é, o destaque de um bem do patrimônio para o pagamento de sua dívida, não valerá.

Após a abordagem dos princípios e requisitos das garantias reais, resta a análise dos seus efeitos.

O primeiro deles é a preferência ou prelação, isto é, o credor com garantia real tem o direito de pagar-se com o produto da venda da coisa dada em garantia excluídos os demais credores. Estes apenas aproveitarão o produto da venda se o credor real for pago integralmente e sobrar dinheiro. Não obstante, caso o produto da venda não seja suficiente para pagar o credor com garantia real, este concorrerá com os demais credores em

\footnotetext{
${ }^{24}$ PEREIRA, Caio Mário da Silva. Instituições de Direito Civil - volume IV, p. 327.
} 
relação ao saldo. Na situação de insolvência do credor, o perfil da garantia real é acentuado. Segundo Caio Mário da Silva Pereira,

alienados em hasta pública os seus bens, que se apura serem insuficientes para solver todas as obrigações, instaura-se concurso de credores, que receberão do acervo comum na proporção dos seus créditos. Mas neste mesmo ensejo, receberá preferencialmente o credor privilegiado, com o produto da venda do bem dado em garantia, gozando assim da faculdade de receber sem se sujeitar ao rateio ${ }^{25}$.

Por outro lado, a preferência dos direitos reais em garantia foi mitigada com a criação legal dos privilégios. São créditos privilegiados aqueles que, por sua natureza, a lei atribui prioridade. Por exemplo: de acordo com o artigo 83 da Lei $n^{0} 11.101$ de 2005, os créditos trabalhistas até 150 (cento e cinqüenta) salários mínimos e os créditos decorrentes de acidente de trabalho são satisfeitos antes dos créditos provenientes de garantias reais.

No entanto, a referida Lei transferiu os créditos tributários, para posição menos favorável do que a prevista no sistema falimentar anterior, que os previa em posição anterior aos créditos reais. Segundo Fabio Ulhôa Coelho, a razão para a preferência dos credores reais sobre os tributários advém do seguinte argumento:

Como a maioria dos credores com garantia real são os bancos, aposta-se que a inversão na ordem de classificação aumentará o volume de recuperação dos créditos abertos a empresários ou sociedades empresárias e, consequientemente, levará à prática de spreads menores ${ }^{26}$.

Já o segundo efeito é o direito de seqüela (artigo 1.419 do Código $\mathrm{Civil}^{27}$ ) que é o direito de reclamar e perseguir a coisa em poder de quem seja para exercer o direito de excussão (a seguir abordado), pois o valor do bem está afeto à satisfação do crédito. Incorporada a coisa ao patrimônio do

\footnotetext{
${ }^{25}$ PEREIRA, Caio Mário da Silva. Instituições de Direito Civil - volume IV, p. 329.

${ }^{26}$ FARIAS \& ROSENVALD. Direitos Reais, p. 609.

27 Art. 1.419. Nas dívidas garantidas por penhor, anticrese ou hipoteca, o bem dado em garantia fica sujeito, por vínculo real, ao cumprimento da obrigação.
} 
adquirente, permanece objeto de garantia do débito do alienante, até a sua solutio $^{28}$.

Decorrente do caráter absoluto dos direito reais, de sua oponibilidade erga omnes, o direito de sequiela é o próprio direito real em ação ${ }^{29}$. Nas palavras de Cristiano Chaves de Farias e Nelson Rosenvald,

a seqüela pode ser explicada e assimilada pela própria essência dos direitos reais. Nessa categoria de direitos subjetivos absolutos, não há qualquer prestação positiva a ser efetuada por uma das partes em favor da outra, exceto o dever geral de abstenção. Em verdade, o titular da garantia real detém uma situação jurídica de poder imediato sobre o objeto afetado ao débito, que lhe permite alcançá-la contra quem com ele estiver, em caráter absoluto ${ }^{30}$.

Por último, o terceiro efeito é a excussão, que está prevista no artigo 1.422 do Código Civil, consiste no direito do credor, caso a dívida esteja vencida e não paga, de promover a venda judicial do bem dado em garantia, para obter o pagamento do débito.

Incide na excussão o princípio prior tempore potior iure, pelo qual o credor da hipoteca registrada em segundo lugar apenas fará jus ao valor do bem excutido após o pagamento do credor da primeira hipoteca. Ademais, a essência do direito real de garantia é o direito que assiste ao credor de se fazer pagar pelo produto resultante da venda da coisa onerada. Este direito subsiste ainda quando a coisa tenha passado para a posse e domínio de qualquer outra pessoa sem o seu consentimento.

Por oportuno, é mister salientar que, além de a excussão poder ser utilizada no termo contratual, pode também ser empregada nas hipóteses de vencimento antecipado da dívida descritas nos artigos 333 e 1.425 do Código Civil, uma vez que se fundamenta na idéia de preservação do valor integral do crédito ou do próprio bem. Complementam Cristiano Chaves de Farias e Nelson Rosenvald que "interessa ao credor evitar que, ao tempo da

\footnotetext{
${ }^{28}$ PEREIRA, Caio Mário da Silva. Instituições de Direito Civil - volume IV, p. 329.

${ }^{29}$ GONÇALVES, Carlos Roberto. Direito Civil Brasileiro - volume V, p. 503.

${ }^{30}$ FARIAS \& ROSENVALD. Direitos Reais, pp. 607-608.
} 
excussão, a transformação do bem dinheiro não sofra diminuição, a ponto de não lhe proporcionar os valores inicialmente pretendidos ${ }^{31}$,.

Finalmente, após a análise do crédito e dos direitos reais de garantia, avança-se ao estudo da alienação fiduciária em garantia de imóvel.

${ }^{31}$ FARIAS \& ROSENVALD. Direitos Reais, p. 613. 


\section{Alienação Fiduciária de Imóvel}

\section{$2.1 \quad$ Histórico}

A alienação fiduciária em garantia possui origem incerta. Ao utilizar o direito comparado, é possível a identificação de diversos institutos jurídicos que podem ter servido de inspiração para o surgimento da alienação fiduciária em garantia em nosso ordenamento. São exemplos a fidúcia romana, o penhor de propriedade germânico, o "trust receipt" e o "mortgage", sendo estes dois últimos presentes no direito anglo-americano.

A fidúcia romana é uma convenção, pela qual aquele que recebeu uma coisa ou um direito, pela mancipatio ou pela in iure cessio, se obriga à restituição, quando satisfeito o fim ou preenchida a destinação. ${ }^{32}$ É nos textos de Gaio que se encontram sua conceituação - uma mancipatio pactuada com a obrigação do adquirente de remancipare, indicado que a mesma se fazia pela mancipatio ou pela in iure cessio - e o registro de suas duas espécies: a fidúcia cum creditore e a fidúcia cum amico. A primeira consistia na venda do bem do devedor ao credor sendo que aquele poderia resgatar o bem se quitasse a dívida no prazo. Já a segunda visava à proteção de bens ameaçados e operava da seguinte forma: o proprietário alienava a coisa ameaçada a um amigo com a condição de poder resgatá-la assim que terminasse o perigo em relação à coisa.

É perceptível que, em ambas espécies, havia transmissão da propriedade do bem sob a condição de retorno ao proprietário-alienante no momento em que a finalidade do contrato fosse cumprida e, conforme salienta Réné Jacqueline, a fidúcia é uma convenção baseada na boa-fé ${ }^{33}$. Isso decore do fato de o fiduciário, tendo propriedade plena sobre o bem, poder dele dispor, desde que, quando satisfeita a dívida, retornasse o bem ao fiduciante.

\footnotetext{
${ }^{32}$ CHALHUB, Melhim Namem. Negócio Fiduciário. Rio de Janeiro: Renovar, 1998. p. 14.

${ }^{33}$ JACQUELINE, René. De La Fiducie, apud CHALHUB, Melhim Namem. Negócio Fiduciário, p. 14.
} 
Ademais, como leciona Melhim Namem Chalhub ${ }^{34}$, a responsabilidade do fiduciário estava sujeita apenas a uma ação pessoal, sujeitando-se o fiduciante aos riscos de insolvência do fiduciário. Nesse sentido, dentre os inconvenientes da fidúcia, José Carlos Moreira Alves aponta, em sua obra de Direito Romano,

(...) que o devedor, para reaver a coisa, ficava, primitivamente, na dependência exclusiva da vontade do credor, pois não dispunha contra este de uma actio (ação) para compeli-lo à restituição da coisa; e, mesmo mais tarde, quando surgiu a actio fiduciae, era ela uma ação pessoal contra o credor, razão por que, se este alienasse a coisa a terceiro, ao invés de restituí-la, o devedor, pela actio fiduciae, podia obter apenas indenização pelo não cumprimento do pacto de restituição da coisa (pactum fiduciae), e não a anulação da venda ao terceiro. ${ }^{35}$

Já através do penhor de propriedade germânico, que apresentava semelhanças com a fidúcia romana, o devedor transferia a propriedade da coisa ao credor, sendo este obrigado a restituir a coisa ao devedor quando ocorresse o adimplemento. Diferencia-se, no entanto, do instituto romano, visto que o caráter resolutório da propriedade do credor é erga omnes.

Assim, caso o fiduciário alienasse a coisa a terceiro, o fiduciante retomava a propriedade da coisa, não ficando sujeito à reparação das perdas e danos da fidúcia romana. Sobre o assunto, Melhim Namem Chalhub citando Martin Wolf destaca que,

enquanto no sistema romano a alienação era incondicional, só existindo uma obrigação pessoal de restituição sujeita à extinção da dívida, já em direito germânico a coisa era transmitida sob condição resolutiva de pagamento da dívida; assim, pois, cumprida a condição, a propriedade voltava ao alienante, assegurada por efeito da condição resolutiva. ${ }^{36}$

No tocante ao "trust receipt" do direito anglo-americano, conceituase como o negócio jurídico em que estão presentes três pessoas: o comprador, o vendedor e o financiador. O primeiro ao comprar mercadorias do segundo, emite recibo ("trust receipt"), indicando que possui a posse da

\footnotetext{
${ }^{34}$ CHALHUB, Melhim Namem. Negócio Fiduciário, p. 14.

${ }^{35}$ ALVES, José Carlos Moreira. Direito Romano. 13 ${ }^{\mathrm{a}}$ ed. Rio de Janeiro: Forense, 2003. p. 351.

${ }^{36}$ BUZAID, Alfredo. Ensaio sobre a alienação fiduciária em garantia. Revista dos Tribunais, vol. 401, p. 9, apud CHALHUB, Melhim Namem. Negócio Fiduciário, p. 19.
} 
mercadoria em nome do financiador. São características deste instituto a possibilidade de o financiado vender a mercadoria para quitar a dívida, sendo o preço mínimo da venda indicado pelo financiador; e a faculdade deste para retomar o bem à sua vontade a qualquer tempo.

Como será possível identificar oportunamente, distingue-se da alienação fiduciária em garantia, uma vez que nesta é vedado ao fiduciante alienar a coisa sem a autorização do fiduciário, ainda que seja para pagar a dívida; e o fiduciário somente poderá retomar o bem em hipótese de inadimplemento. ${ }^{37}$

Por fim, o "mortgage", também do direito anglo-americano, é a transmissão da propriedade com fins assecuratórios. É figura próxima à alienação fiduciária em garantia, visto que, a propriedade do fiduciário é resolúvel. Adimplida a dívida do fiduciante, é neste consolidada a propriedade do bem.

Diverge da fidúcia romana, uma vez que, após um processo evolutivo do "mortage", o devedor inadimplente passa a ter a faculdade de reaver o bem no prazo de 12 (doze) $\operatorname{anos}^{38}$, caso pague a dívida, os juros e uma reparação pela mora. Nesse sentido, registra Melhim Namem Chalhub:

É nesse contexto que se constrói a "equity of redemption", pela qual a Corte confere ao devedor, mesmo depois de vencido o prazo do contrato, o direito de obter a restituição da coisa dentro de um prazo razoável, desde que pagasse a dívida, mais os juros e uma reparação pela mora.

De outra parte, assiste ao credor o direito de propor que a Corte imponha ao devedor a obrigação de exercitar a "equity of redemption" dentro do prazo, sob pena de perder definitivamente a propriedade. Para evitar esse processo, as partes passaram a incluir, no "mortgage" uma cláusula autorizando o credor a vender o bem em caso de falta de pagamento.

É assim, como decorrência desse processo evolutivo, que se afastam os conceitos de "mortgage" e da fiducia cum creditore, apesar de ambos, na fase genética, terem tido estruturas exatamente iguais, pois se tratava de negócio jurídico que, de fato, tinham como antecedente lógico um vínculo obrigacional entre fiduciante e fiduciário, no qual o fiduciante

\footnotetext{
${ }^{37}$ SAAD, Renan Miguel. A alienação fiduciária sobre bens imóveis. Rio de Janeiro: Renovar, 2001. p. 59.

${ }^{38}$ SAAD, Renan Miguel. A alienação fiduciária sobre bens imóveis, p. 61.
} 
tinha a qualidade de devedor da prestação e o fiduciário a de credor, sendo essa a obrigação que se tratava garantir. ${ }^{39}$

Finalmente, feita a breve análise, é possível perceber que todos os institutos mencionados, apesar de próximos, apresentam peculiaridades para atenderem às necessidades de cada sociedade e ordenamento jurídico a que pertencem, pois parafraseando Armando Castelar Pinheiro e Jairo Saddi, "o direito é fruto de uma época histórica que tem, sobretudo, determinantes econômicos. $^{40}$. Não foi diferente com o direito pátrio. Nosso instituto da alienação fiduciária em garantia surgiu para acompanhar as necessidades geradas pela vida moderna insatisfeita com aqueles de cunho tradicional, como o penhor e a hipoteca. $^{4142}$.

É novo tipo de garantia que facilita o acesso ao crédito, pois dá maior segurança jurídica ao credor, visto que prevê execução célere do seu crédito. Apesar de suas vantagens, tal garantia não apareceu em nosso ordenamento até meados dos anos 60. De acordo com Caio Mário da Silva Pereira,

a supressão da fidúcia do Corpus Ius Civilis do século VI importou em que não recebeu acolhida nos sistemas romano-cristãos. Não penetrou no Código Civil Francês de 1804, nem no BGB de 1896, e em consequiência os Códigos todos, filiados à corrente napoleônica e à tedesca, o ignoraram. Inclusive o brasileiro de 1916.(...) Deixando de ser negócio jurídico contratual típico, nem por isso ficou entre nós repudiado inteiramente. Filho órfão, e mesmo enjeitado, encontrou todavia abrigo em uma e outra manifestação esporádica. A doutrina não o desconhecia de todo, e os tribunais, embora com certa relutância e alguma vacilação, entenderam que não seria uma figura contratual contrária ao nosso sistema. $^{43}$

Vale lembrar que apesar de comentada na doutrina, pelo princípio da tipicidade, somente lei pode criar direitos reais. Assim, a garantia fiduciária,

\footnotetext{
${ }^{39}$ CHALHUB, Melhim Namem. Negócio Fiduciário, p. 21.

${ }^{40}$ PINHEIRO \& SADDI. Direito, Economia e Mercados. p. 85.

${ }^{41}$ PEREIRA, Caio Mário da Silva. Instituições de Direito Civil - volume IV, p. 423.

42 De fato as garantias existentes nos sistemas jurídicos de origem romana, e são elas a hipoteca, o penhor e a anticrese, não mais satisfazem a uma sociedade industrializada, nem mesmo nas relações creditícias entre pessoas físicas, pois apresentam graves desvantagens pelo custo e morosidade em executá-las. (ALVES, José Carlos Moreira. Alienação Fiduciária em Garantia, apud CHALHUB, Melhim Namem. Negócio Fiduciário, p. 195.).

${ }^{43}$ PEREIRA, Caio Mário da Silva. Instituições de Direito Civil-volume IV, p. 424.
} 
inicialmente restrita à bens móveis, logrou ingresso na legislação pátria com a promulgação da lei especial de disciplina do mercado de capitais (Lei $\mathrm{n}^{\circ}$ 4.728/1965), modificada pelo Decreto-Lei 911/1969.

Posteriormente, a fim de fomentar o acesso ao crédito para aquisição de imóveis, foi prevista na Lei $n^{0}$ 9.514/1997, que além de criar o Sistema de Financiamento Imobiliário, disciplinou o regime jurídico da alienação fiduciária de bens imóveis. A respeito da criação da alienação fiduciária de imóveis, afirmam Cristiano Chaves de Farias e Nelson Rosenvald que:

O legislador tenciona criar meios mais céleres para o credor fiduciário recuperar seu crédito, em substituição ao Sistema Financeiro de Habitação, no qual preponderava a execução da garantia hipotecária, que perdeu a credibilidade em razão de gerar um processo judicial extremamente demorado e oneroso que inviabilizava a própria concessão do crédito habitacional. Ademais, há sério questionamento em face da constitucionalidade do Processo de execução hipotecária, reservado ao DL n ${ }^{\circ} 70$ de $1966^{44}$.

Frederico Henrique Viegas de Lima completa:

O modelo usual de hipoteca existente no direito brasileiro é incapaz de dotar os negócios imobiliários da rapidez indispensável, requerida pela economia de escala como solução para a recuperação do crédito concedido, caso exista a impontualidade do devedor (...) As execuções hipotecárias são procedimentos judiciais infindáveis, arrastando-se nos foros judiciais por anos a fio, acobertadas por um sistema recursal que protege aquela parte que deseja procrastinar o feito. (...) Muitas vezes o credor se vê compelido a adjudicação do imóvel, coisa que no momento da concessão do crédito não era sua intenção ${ }^{45}$.

O Código Civil de 2002 recepcionou no artigo 1.225 a propriedade fiduciária sobre bens móveis.

Ao analisar o referido artigo do novo Código Civil, pode-se perceber que não há referência à alienação fiduciária. Cristiano Chaves e Nelson Rosenvald explicam que isso se deve ao fato de antes do Código Civil de 2002 a alienação fiduciária ser tratada como direito real de garantia, sendo depois do mesmo tratada como tipo contratual. Nessa trilha, ensina José Carlos Moreira Alves:

\footnotetext{
${ }^{44}$ FARIAS \& ROSENVALD. Direitos Reais, p. 385.

${ }^{45}$ LIMA, Frederico Henrique Viegas de. Da alienação fiduciária em garantia de coisa imóvel. $2^{\mathrm{a}}$ ed. Curitiba: Juruá Editora, 2006. pp. 32-33.
} 
Os autores que se têm ocupado, em nosso país, com a alienação fiduciária em garantia não fazem, com a necessária nitidez, distinção que é indispensável para o estudo sistemático desse instituto jurídico. Dão eles a impressão de que a alienação fiduciária é nova forma de garantia real. E daí nascem erros inadmissíveis, pois a alienação fiduciária não é modalidade de garantia real, tal qual não o são o contrato de penhor e o contrato de hipoteca. O penhor e a hipoteca é que são espécies de garantia real ${ }^{46}$.

Assim, após o Código Civil de 2002, o que é espécie de garantia real é a propriedade fiduciária prevista implicitamente no artigo 1.225 inciso I, pois é espécie de propriedade resolúvel; enquanto a alienação fiduciária é forma contratual.

Por fim, ressalta-se que a Lei $\mathrm{n}^{0} 10.391$ de 2004 alterou o Código Civil de 2002 no que tange à propriedade fiduciária, a fim de incluir o artigo $1.368-\mathrm{A}^{47}$ para dispor que se submetem às leis especiais (como é o caso da Lei $n^{\circ} 9.514$ de 1997) as demais espécies de propriedade fiduciária, sendo aplicadas as normas do Código Civil naquilo que não for incompatível.

Portanto, a alienação fiduciária em garantia de bens imóveis, tema da presente monografia, é tratada na Lei $\mathrm{n}^{0} 9.514$ de 1997, sendo-lhe aplicáveis as normas gerais do Código Civil no que diz respeito à propriedade fiduciária no que for compatível.

\section{$2.2 \quad$ Instituto}

Conforme abordado no capítulo anterior, a alienação fiduciária surgiu para estimular o financiamento imobiliário, atingindo relevante grau de importância na sociedade, visto que difere das demais garantias reais, pois nestas, penhor, anticrese e hipoteca, o titular da garantia tem um direito

\footnotetext{
${ }^{46}$ ALVES, José Carlos Moreira. Da alienação fiduciária em garantia apud FARIAS \& ROSENVALD. Direitos Reais, p. 365.

${ }^{47}$ Art. 1.368-A. As demais espécies de propriedade fiduciária ou de titularidade fiduciária submetem-se à disciplina específica das respectivas leis especiais, somente se aplicando as disposições deste Código naquilo que não for incompatível com a legislação especial.
} 
real na coisa alheia, enquanto na propriedade fiduciária o titular da garantia é titular de direito de propriedade, embora limitado pelo caráter fiduciário ${ }^{48}$.

Assim, a alienação fiduciária em garantia de imóveis, instituída pela Lei $n^{0} 9.514$ de 1997, é o negócio jurídico pelo qual o devedor, fiduciante, entrega a propriedade de um bem ao credor, fiduciário, ficando apenas com a sua posse direta, a fim de assegurar outro negócio jurídico. Se a dívida deste negócio jurídico for quitada no prazo contratual estabelecido, a propriedade do bem resolver-se-á perante o fiduciário, retornando ao fiduciante, caso contrário, consolidar-se-á perante o fiduciário, que através de um procedimento extrajudicial, criado pela Lei em comento, terá a recuperação rápida e simplificada de seu crédito.

A alienação fiduciária imobiliária é negócio jurídico acessório, pois assegura um negócio jurídico principal, usualmente, de mútuo; típico, pois sua estrutura e características são previstas Lei $\mathrm{n}^{0} 9.514$ de 1997; formal, pois a lei estabelece as formalidades para sua feitura; e oneroso, pois ambas as partes possuem obrigações.

O artigo 22 da Lei ${ }^{\circ} 9.514$ de 1997 preceitua que:

Art. 22. A alienação fiduciária regulada por esta Lei é o negócio jurídico pelo qual o devedor, ou fiduciante, com o escopo de garantia, contrata a transferência ao credor, ou fiduciário, da propriedade resolúvel de coisa imóvel; e

Em relação à transmissão da propriedade do bem ao credor, é a mesma chamada de fiduciária, isto é, a transmissão dessa propriedade tem caráter transitório e temporário, visto que o credor adquire o bem como forma de garantia até que o devedor pague a dívida e não com o intuito de ficar com o bem para si ${ }^{49}$. Estabelece o artigo. 23 da Lei ${ }^{\circ} 9.514$ de 1997:

\footnotetext{
${ }^{48}$ CHALHUB, Melhim Namem. Negócio Fiduciário, pp. 200-201.

${ }^{49}$ No mesmo sentido, ensina Afrânio Carlos Camargo Dantzger que "a intenção do fiduciante se mostra como um dos aspectos mais importantes do negócio, pois o seu propósito não é transmitir de forma plena e definitiva a propriedade do imóvel para o fiduciário, antes, a transmissão se deve dar de uma forma temporária, com a intenção insofismável de que apenas servirá o negócio como garantia de um crédito". Além disso, cita o jurista José Carlos Moreira Alves, a fím de afirmar que após transmitir a propriedade ao credor, o devedor possui um direito expectativo à aquisição da propriedade. Expressa que se trata de um direito expectativo de caráter real, visto que o fiduciante enquanto não quita a dívida, não é mero possuidor direto do imóvel, pois "um plus se acrescenta
} 
Art. 23. Constitui-se a propriedade fiduciária de coisa imóvel mediante registro, no competente Registro de Imóveis, do contrato que lhe serve de título.

Parágrafo único. Com a constituição da propriedade fiduciária, dá-se o desdobramento da posse, tornando-se o fiduciante possuidor direto e o fiduciário possuidor indireto da coisa imóvel.

\subsubsection{Propriedade Fiduciária Imobiliária}

Como bem ressalta Frederico Henrique Viegas de Lima, não se confundem alienação fiduciária de coisa imóvel e propriedade fiduciária. Esta, como forma de propriedade, só passa a existir com o registro do contrato no Registro Geral de Imóveis, visto que nosso ordenamento jurídico, diferentemente do francês, não admite a simples manifestação de vontade como modo de aquisição da propriedade ${ }^{50}$. Até o registro do contrato, existe somente o negócio jurídico de atribuição patrimonial, consubstanciado no contrato de direito das coisas. Diz o jurista:

A contratação da alienação fiduciária é negócio jurídico diverso da propriedade fiduciária que passará a existir no momento em que o contrato for levado a registro no ofício imobiliário competente. Daí, a importante distinção que deve ser efetuada entre alienação fiduciária e constituição da propriedade fiduciária em favor do credor fiduciário. (...) Portanto, o título aquisitivo não é o bastante para a perfectibilização da transferência da propriedade - quer seja plena, quer resolúvel. É indispensável um outro momento, que caracterize no caso concreto da alienação fiduciária de coisa imóvel, o modo de adquirir pela transcrição do título, consubstanciado no registro do contrato alienativo no registro imobiliário da situação do imóvel. Só a partir do registro passa a existir a propriedade fiduciária, estabelecida em favor do credor. Até então, temos um contrato, de cunho obrigacional, que gera a obrigação de transferir a propriedade, por meio resolúvel, surgindo, por consequiência a propriedade fiduciária $^{51}$.

ao conjunto de seus direitos, a saber, a absoluta certeza de recuperar, automaticamente e por força de lei, o domínio do indigitado imóvel tão logo satisfeito o crédito do fiduciário. (DANTZGER, Afrânio Carlos Camargo. Alienação Fiduciária de Bens Imóveis. $2^{\mathrm{a}}$ ed. São Paulo: Método, 2007. p. 61.)".

${ }^{50}$ Como ensina Caio Mario da Silva Pereira, “como negócio translativo da propriedade, não vale o contrato por si só, pois o nosso direito não reconhece efeitos reais aos contratos". (PEREIRA, Caio Mário da Silva. Instituições de Direito Civil - volume IV, p. 426.).

${ }^{51}$ LIMA, Frederico Henrique Viegas de. Da alienação fiduciária em garantia de coisa imóvel, p. 42. 
Antes de adentrar nas características da propriedade fiduciária imobiliária, é mister lembrar que, apesar de o artigo 33 da Lei $n^{\circ} 9.514$ de 1997 prever a aplicação dos artigos 1.359 e 1.360 do Código Civil sobre a propriedade resolúvel, a propriedade fiduciária imobiliária tem características próprias.

A propriedade resolúvel pura e simples é propriedade plena, apenas limitada pelo tempo. A vontade das partes estabelece quando a propriedade se inicia e quando cessará. A causa de extinção pode ser vinculada a uma condição ou a um termo e fará parte do título que a instituiu. Ademais, tendo o proprietário resolúvel a plenitude dos direitos da propriedade, admite-se, inclusive que possa dispor de seu direito, embora não possa alienar mais do que tem. Assim, pode ceder a integralidade da propriedade resolúvel, ou constituir direitos reais de garantia, enquanto durar o seu direito $^{52}$.

No que tange à propriedade fiduciária imobiliária, estas características não estão presentes. Em primeiro lugar, a constituição da propriedade fiduciária imobiliária não advém da vontade das partes, mas sim, da força da lei, mais precisamente, através do artigo 23 da Lei $\mathrm{n}^{\circ} 9.514$ de 1997, tornando, dessa forma, negócio jurídico típico.

Em segundo lugar, sua extinção tampouco deriva da vontade das partes, decorrendo, neste caso, também, da lei. O artigo 25 da Lei $\mathrm{n}^{\circ} 9.514$ de 1997 prevê, além do momento da extinção da propriedade fiduciária imobiliária, a forma como se operará:

Art. 25. Com o pagamento da dívida e seus encargos, resolve-se nos termos deste artigo, a propriedade fiduciária do imóvel.

$\$ 1^{\circ}$ No prazo de trinta dias, a contar da data de liquidação da dívida, o fiduciário fornecerá o respectivo termo de quitação ao fiduciante, sob pena de multa em favor deste, equivalente a meio por cento ao mês, ou fração sobre o valor do contrato.

$\S 2^{\circ}$ À vista do termo de quitação de que trata o parágrafo anterior, o oficial do competente Registro de Imóveis efetuará o cancelamento do registro da propriedade fiduciária.

\footnotetext{
${ }^{52}$ LIMA, Frederico Henrique Viegas de. Da alienação fiduciária em garantia de coisa imóvel, p. 66.
} 
Por fim, o credor fiduciário não possui todas as faculdades inerentes ao domínio. Diferentemente da propriedade resolúvel, não pode constituir outros direitos reais sobre a coisa durante a pendência da obrigação principal $^{53}$.

É característico da propriedade fiduciária imobiliária o desdobramento da posse. Também caracteriza a referida propriedade na ocasião do vencimento da obrigação principal e configurado o inadimplemento: o retorno da propriedade plena ao fiduciante caso purgue a mora; a consolidação da propriedade na pessoa do credor fiduciário, que tem a obrigação de realizar a venda pública da mesma; a transmissão da propriedade plena ao arrematante que adquiriu o bem em leilão.

O desdobramento da posse está previsto no artigo 23 da Lei $n^{\circ} 9.514$ de 1997.

A posse direta é a que possui o devedor fiduciante. Compreende na apreensão física da coisa ${ }^{54}$, pois tem o direito de usar e gozar do bem sujeito à propriedade fiduciária. Destaca-se que, como deriva da posse indireta, está adstrita às faculdades dominiais que lhe foram transferidas. Por outro lado, a posse indireta é aquela detida pelo credor fiduciário como conseqüência do seu domínio sobre a coisa - é a posse à distância ${ }^{55}$. É a posse que o proprietário conserva quando temporariamente cede a outro o poder de fato sobre a coisa ${ }^{56}$. Ademais, é a posse indireta que legitima a reintegração de posse se inadimplente o devedor, bem como concede poderes fiscalizatórios ao credor, com relação ao mau uso da coisa, sua conservação física e pagamento dos tributos sobre ele incidentes ${ }^{57}$. A

\footnotetext{
${ }^{53}$ LIMA, Frederico Henrique Viegas de. Da alienação fiduciária em garantia de coisa imóvel, p. 70.

${ }^{54}$ FARIAS \& ROSENVALD. Direitos Reais, p. 59.

${ }^{55}$ MEZZARI, Mario Pazutti. Alienação Fiduciária da Lei n. 9.514, de 20-11-1997. São Paulo: Saraiva, 1998. p. 52.

${ }^{56}$ FARIAS \& ROSENVALD. Direitos Reais, p. 60.

${ }^{57}$ É importante ressaltar que o credor, proprietário fiduciário, é o contribuinte direto dos tributos, taxas e demais ônus que incidam sobre o imóvel, como, por exemplo, do Imposto Predial e Territorial Urbano ou Imposto Territorial Rural, contribuições de melhoria e contribuições condominiais, enfim, das obrigações propter rem. Assim, embora o credor fiduciário e o devedor fiduciante possam estipular que o pagamento dos mencionados encargos seja obrigação do fiduciante, conforme previsão dos $\$ 1^{\circ}$ do artigo 26 e $\$ 2^{\circ}$ do artigo 27 da Lei $n^{\circ} 9.514$ de 1997 ,
} 
pretensão do possuidor indireto frente ao direto extingue-se apenas com o adimplemento do devedor, momento em que se operará a reunião das posses na figura do devedor que passará a ter a posse plena ${ }^{58}$.

Outra característica da propriedade fiduciária imobiliária é a consolidação da propriedade em favor do credor em razão do inadimplemento do devedor. Inicialmente, explica-se que a inadimplência deste, conforme artigo 26 da Lei $\mathrm{n}^{\circ} 9.514$ de 1997, tem por requisito a caracterização da mora. Esta decorrerá da notificação do devedor fiduciante feita pelo oficial do Registro de Imóveis competente para pagamento da prestação vencida e de seus acréscimos moratórios. Caso o devedor, constituído em mora, não pague a dívida, a propriedade consolidar-se-á em favor do credor fiduciário.

Entretanto, alerta-se que, embora haja a reunião das duas posses na figura do credor, este não terá a propriedade plena sobre a coisa, pois é característico dos direitos reais em garantia a vedação do pacto comissório, isto é, da cláusula contratual que autoriza o credor a ficar em definitivo com a coisa dada em garantia, por força da inadimplência ${ }^{5960}$. Neste diapasão, reza o artigo 27 da Lei $n^{0} 9.514$ de $1997^{61}$, que o credor, no prazo de trinta dias, promoverá o primeiro público leilão para a venda do bem. Nas palavras de Frederico Henrique Viegas de Lima:

perante o credor dos encargos, o credor fiduciário será o responsável pelo pagamento, pois as convenções particulares não podem ser opostas aos credores públicos ou particulares. (MEZZARI, Mario Pazutti. Alienação Fiduciária da Lei n. 9.514, de 20-11-1997, p. 53.).

${ }^{58}$ A pretensão possessória em favor do credor fiduciário existe desde o momento em que surge a propriedade fiduciária (...) e persiste até o momento em que o devedor fiduciante realiza o adimplemento da obrigação principal. (...) podendo, até mesmo, persistir quando há o inadimplemento da obrigação principal, por parte do devedor fiduciante. Acrescente-se que, em reforço desta situação, mesmo na hipótese de o devedor fiduciante inadimplente permanecer na posse da propriedade fiduciária - sob a modalidade de posse injusta-, tanto o credor fiduciário quanto o eventual terceiro adquirente do imóvel em público leilão possuem proteção possessória frente àquele, de maneira a serem reintegrados na posse. (LIMA, Frederico Henrique Viegas de. Da alienação fiduciária em garantia de coisa imóvel, p. 73.).

${ }^{59}$ FARIAS \& ROSENVALD. Direitos Reais, p. 613.

${ }^{60}$ No mesmo sentido, afirma o mestre Caio Mario da Silva Pereira que é o pacto comissório técnica opressiva do economicamente mais fraco repulsada já no Direito Romano. Posteriormente, tal repulsa espalhou-se por toda a legislação ocidental. Diz ainda que é "nulidade insuscetível de ser sanada. É cláusula ineficaz, ainda que mascarada sob a forma de compra e venda com pacto de resgate". (PEREIRA, Caio Mário da Silva. Instituições de Direito Civil - volume IV, p. 333.).

${ }^{61}$ Art. 27. Uma vez consolidada a propriedade em seu nome, o fiduciário, no prazo de trinta dias, contados da data do registro de que trata o $\$ 7^{\circ}$ do artigo anterior, promoverá público leilão para a alienação do imóvel. 
(...) o credor fiduciante, tendo a propriedade consolidada em seu favor, possui o ônus de aliená-la no prazo de trinta dias, contados da data do registro que efetivou a consolidação. Portanto, não se pode falar em propriedade plena em favor do credor fiduciário, mas sim, em propriedade limitada com escopo de garantia. (...) O credor fiduciário só passará a ter a propriedade (...) caso o segundo leilão se frustre, a dívida será considerada extinta e a propriedade do credor que até então era limitada com escopo de garantia, passa a ser considerada plena e ilimitada, sendo inclusive passível de ser alienada livremente a quem melhor convier ao credor fiduciário, ou mesmo conservá-la em seu patrimônio $(. . .)^{62}$.

A hipótese de plenitude da propriedade do credor descrita pelo jurista está presente no $§ 8^{\circ}$ do artigo 26 da Lei $n^{\circ} 9.514$ de 1997 . Vale dizer que esta disposição não mascara a vedação do pacto comissório, tendo em vista que, as partes à época do inadimplemento podem transacionar a entrega do bem como operação de dação em pagamento ${ }^{63}$. Explica Caio Mário da Silva Pereira que:

é licita a convenção pela qual o devedor, após o vencimento da obrigação, entregar em pagamento da dívida a mesma coisa ao credor que a aceita liberando-o (datio in solutum), pelo fato de aí não mais vigorar o mesmo fundamento ético ${ }^{64}$.

Como última característica da propriedade fiduciária imobiliária a ser tratada tem-se a consolidação da propriedade em favor do adquirente em público leilão. Conforme explicado, a propriedade consolidada em favor do credor decorrente do inadimplemento do devedor não é plena. No entanto, quando o adquirente compra do credor o bem no público leilão, está adquirindo a propriedade plena sobre o bem, livre de qualquer ônus. Eis aqui outra particularidade que acentua as diferenças existentes entre a propriedade fiduciária imobiliária e a propriedade resolúvel. Sobre o tema, aborda José Carlos Moreira Alves:

\footnotetext{
${ }^{62}$ LIMA, Frederico Henrique Viegas de. Da alienação fiduciária em garantia de coisa imóvel, pp. 75-77.

${ }^{63}$ Dispõe o Código Civil: Art. 1.428. É nula a cláusula que autoriza o credor pignoratício ou hipotecário a ficar com o objeto da garantia, se a dívida não for paga no vencimento. Parágrafo único. Após o vencimento, poderá o devedor dar a coisa em pagamento da dívida.

${ }^{64}$ PEREIRA, Caio Mário da Silva. Instituições de Direito Civil - volume IV, p. 333.
} 
É ela uma propriedade - além de resolúvel - limitada pela lei para atender ao escopo de garantia para o qual foi criada. Enquanto esse escopo perdura, a lei atua como elemento de compressão sobre o conteúdo do domínio atribuído ao credor; deixando de ser necessária a garantia, cessa a pressão, e, automaticamente, a propriedade volta à sua plenitude anterior. Por isso, o credor, pendente conditione iuris ou defecta conditione iuris (neste caso, antes da venda da coisa alienada fiduciariamente), é titular de domínio bastante restrito que é a propriedade fiduciária. Neste instante, porém, em que, não pago o débito pelo devedor, aliena o credor a coisa a terceiro, este adquire domínio pleno sobre ela, sem qualquer violação ao princípio nemo ad alium plus iuris transferre potest quam ipse habet, mas em virtude do simples fato de que o escopo de garantia desapareceu com a obtenção do credor, pelo preço que lhe permitir satisfazer, total ou parcialmente, o crédito ${ }^{6566}$.

\subsubsection{Requisitos}

Apesar de os requisitos para constituição de direitos reais de garantia já terem sido apreciados no capítulo anterior, é forçoso analisar os requisitos da Lei $n^{\circ} 9.514$ de 1997 , porque esta traz algumas especificidades para o contrato de alienação fiduciária em garantia de bem imóvel. São requisitos de validade: subjetivos, objetivos e formais.

\subsubsection{Requisitos Subjetivos}

No contrato de alienação fiduciária em garantia, são sujeitos o fiduciário e o fiduciante. Conceitua-se fiduciário o credor, ou seja, aquele que adquire a propriedade fiduciária do bem. Por outro lado, é chamado fiduciante o devedor, quem aliena o bem em garantia objetivando garantir uma obrigação principal, da qual, geralmente, é o beneficiário.

À época da instituição da alienação fiduciária em garantia de bens móveis, por meio da Lei $\mathrm{n}^{\circ} 4.728$ de 1965, havia um grande questionamento sobre a legitimidade para ser credor, visto que a mencionada Lei versa

\footnotetext{
65 ALVES, José Carlos Moreira. Da Alienação Fiduciária em Garantia, apud LIMA, Frederico Henrique Viegas de. Da alienação fiduciária em garantia de coisa imóvel, pp. 77-78.

${ }^{66}$ Consoante a este entendimento, Frederico Henrique Viegas de Lima afirma que "o leilão efetuado transcende a relação jurídica até então existente entre o devedor fiduciante e credor fiduciário, razão pela qual a transferência da propriedade para um terceiro deve ser plena, sem qualquer limitação". (LIMA, Frederico Henrique Viegas de. Da alienação fiduciária em garantia de coisa imóvel, pp. 79.).
} 
sobre o Mercado de Capitais. Dessa forma, doutrina e jurisprudência eram pacíficas no sentido de que somente poderiam ser fiduciárias as instituições financeiras ou sociedades de crédito.

Entretanto, como bem relata Renan Miguel Saad, aos poucos, a jurisprudência do Excelso Pretório pacificou o entendimento sobre a possibilidade de alienação fiduciária de bens adquiridos em consórcio ${ }^{67}$, sendo, hodiernamente, possível que qualquer tipo de pessoa jurídica seja qualificada como fiduciária.

No que tange à alienação fiduciária em garantia sobre bem imóvel, apesar de a Lei n ${ }^{0} 9.514$ de 1997 versar sobre Sistema de Financiamento Imobiliário, não há óbice para que quaisquer pessoas físicas ou jurídicas possam atuar como fiduciante ou fiduciário independentemente de participação no $\mathrm{SFI}^{68}$, pois a redação do artigo $22 \S 1^{\circ}$ da Lei é cristalina neste sentido:

Art. 22. $\S 1^{\circ}$. A alienação fiduciária poderá ser contratada por pessoa física ou jurídica, não sendo privativa das entidades que operam o SFI, podendo ter como objeto, além da propriedade plena:

Melhim Namem Chalhub elucida que a generalização da legitimidade decorre da intenção do legislador. É ler:

Diferentemente, a Lei $\mathrm{n}^{\circ} 9.514$ de 1997, que instituiu o Sistema de Financiamento Imobiliário e disciplinou a alienação fiduciária em garantia sobre bens imóveis, atribuiu legitimidade para contratação dessa alienação a qualquer pessoa, quer física, quer jurídica, não restringindo às entidades que operam no mencionado Sistema. Com a generalização, o legislador deixa clara sua intenção de dotar o setor imobiliário, em toda a sua amplitude, de um novo instrumento para dinamização de suas atividades, em atenção à sua função multiplicadora na economia e à sua capacidade de geração de empregos em larga escala, e, em especial, viabilizar o funcionamento do mercado secundário de créditos imobiliários $^{69}$.

\footnotetext{
${ }^{67}$ SAAD, Renan Miguel. A alienação fiduciária sobre bens imóveis, p. 144.

${ }^{68}$ São legitimados para atuar no Sistema de Financiamento imobiliário as pessoas indicadas no artigo $2^{\circ}$ da Lei $\mathrm{n}^{\circ} 9.514$ de 1997 :

Art. $2^{\circ}$ Poderão operar no SFI as caixas econômicas, os bancos comerciais, os bancos de investimento, os bancos com carteira de crédito imobiliário, as sociedades de crédito imobiliário, as associações de poupança e empréstimo, as companhias hipotecárias e, a critério do Conselho Monetário Nacional - CMN, outras entidades.

${ }^{69}$ CHALHUB, Melhim Namem. Negócio Fiduciário, pp. 202-203.
} 
Assim, superado ponto sobre a legitimidade para contratar a alienação fiduciária em garantia sobre bens imóveis, faz-se necessário analisar a aplicação da mesma.

Muito embora se faculte sua utilização nas operações de crédito, é no mercado de incorporações imobiliárias que a alienação fiduciária é mais utilizada, podendo ser vislumbradas diferentes formas de contratação.

$\mathrm{Na}$ primeira, incorporadora e adquirente celebram dois contratos coligados: um de compra e venda do bem a ser construído com pagamento parcelado, tendo o adquirente reconhecido que deve o saldo do preço; e outro de alienação fiduciária em garantia sobre o imóvel. Neste, o comprador aliena fiduciariamente o bem que acabou de adquirir com o intuito de garantir o pagamento daquele contrato. Figuram, portanto, o incorporador como vendedor e credor fiduciário e o adquirente como comprador e devedor fiduciante.

$\mathrm{Na}$ segunda hipótese, tem-se adicionalmente a presença de uma instituição financeira que atuará como financiadora do adquirente. Melhim Namem Chalhub resume esta hipótese da seguinte forma:

Na dinâmica deste tipo de operação, a financiadora celebrará com o adquirente dois contratos: primeiro o de financiamento e depois o de alienação fiduciária; o contrato de financiamento está no nascedouro desse conjunto de operações, que obedecerá invariavelmente a seguinte sequiência: $\left(1^{\circ}\right)$ financiamento (origem dos recursos para a compra), $\left(2^{\circ}\right)$ compra e venda (pagamento com os recursos do financiamento) e $\left(3^{\circ}\right)$ alienação fiduciária (transmissão da propriedade do imóvel recémadquirido, para fins de garantia do financiamento). O adquirente será, num primeiro momento, o tomador do financiamento $\mathrm{e}$, conseqüentemente, devedor, num segundo momento, será o adquirente propriamente (quando contrata a aquisição com o incorporadorvendedor); e num terceiro momento (depois de já ter adquirido o imóvel) será devedor-fiduciante, quando, tendo reconhecido a dívida, transmitirá à financiadora a propriedade fiduciária do imóvel que adquirira, em garantia do pagamento da dívida; assim, figurará ele no conjunto de contratos na posição de $\left(1^{\circ}\right)$ devedor, $\left(2^{\circ}\right)$ adquirente e $\left(3^{\circ}\right)$ devedorfiduciante ${ }^{70}$.

\footnotetext{
${ }^{70}$ CHALHUB, Melhim Namem. Negócio Fiduciário, p. 205.
} 
Fora do âmbito das incorporações imobiliárias, pode-se utilizar a alienação fiduciária em garantia para qualquer operação de crédito, em substituição à hipoteca. Nesta situação, o beneficiário do empréstimo, alienará fiduciariamente um bem que já possui ou, ainda, um terceiro atuará como interveniente garantidor. É o caso de o bem a ser alienado em garantia ao fiduciário não ser de propriedade do fiduciante, mas sim de terceiro, que, nas palavras de Frederico Henrique Viegas de Lima, "comparece na contratação com a exclusiva finalidade de prestar a garantia. $^{71,}$

Por fim, merece atenção o instituto da cessão da posição do fiduciário e do fiduciante. Antes da análise de ambas as situações, é preciso ter em mente que o cessionário, seja como novo fiduciário ou como novo fiduciante, necessita preencher os requisitos subjetivos tratados. Assim, poderá ser pessoa física ou jurídica mesmo que não integrante do Sistema de Financiamento Imobiliário (SFI) e deverá ser pessoa capaz ${ }^{7273}$ com poderes de disposição.

\subsection{Cessão da posição do fiduciário}

A cessão da posição do fiduciário é de suma importância para o mercado imobiliário, pois concretiza o giro de suas operações. Melhim Namem Chalhub observa que

para o regular funcionamento do mercado secundário de créditos imobiliários, é indispensável a cessão do crédito com sua garantia, pois é por meio da cessão do crédito que o originador do crédito transmiti-lo-á à companhia securitizadora e esta, como cessionária do crédito, emitirá

\footnotetext{
${ }^{71}$ LIMA, Frederico Henrique Viegas de. Da alienação fiduciária em garantia de coisa imóvel, p. 82.

${ }^{72}$ Vale lembrar que a pessoa pode ser assistida ou representada, se relativa ou absolutamente incapaz respectivamente.

${ }^{73}$ Devem ambas as partes ter capacidade para contratar, notadamente para dispor de seus bens, pois este contrato encerra a transmissão da propriedade de um imóvel do devedor-fiduciante para o credor-fiduciário e, subseqüentemente, a reversão da propriedade para o fiduciante, se realizada a condição, ou sua transmissão do fiduciário para terceiro (neste último caso, se se frustrar a condição a que está subordinado o negócio, a propriedade se consolida no fiduciário e este aliena o imóvel a terceiro, para satisfação do seu crédito). Importa, portanto, que ambos os contratantes tenham capacidade para alienar. (CHALHUB, Melhim Namem. Negócio Fiduciário, p. 202.).
} 
títulos a ele correspondentes para colocação no mercado financeiro ou de títulos e valores mobiliários. É esse o mercado que constituirá a fonte de recursos para o mercado imobiliário, viabilizando o giro contínuo das atividades do setor ${ }^{74}$.

\title{
Preceitua o artigo 28 da Lei ${ }^{\circ} 9.514$ de 1997 que
}

Art. 28. A cessão do crédito objeto da alienação fiduciária implicará a transferência, ao cessionário, de todos os direitos e obrigações inerentes à propriedade fiduciária em garantia.

Cedendo o fiduciário sua posição para terceiro, este o substitui no contrato e assumirá seus direitos e suas obrigações ${ }^{75}$; em outras palavras, tornar-se -á titular de uma propriedade fiduciária, tendo o direito de receber o crédito e seus acessórios e obrigando-se a restituir a propriedade do imóvel ao fiduciante no momento em que quitar a dívida. No mesmo sentido, destaca-se abaixo excerto de recente acórdão do Tribunal de Justiça do Rio de Janeiro que manteve extinta a ação proposta pela fiduciante contra o cedente fiduciário:

\author{
TRIBUNAL DE JUSTIÇA DO RIO DE JANEIRO \\ 19 Câmara Cível \\ Origem: $3^{\text {a }}$ Vara Cível - Regional Barra da Tijuca \\ Apelação Cível n ${ }^{\circ}$ 2007.001.64492 \\ Apelantes: Andréia Macedo Guedes e Marcus Vinícius de Souza \\ Medeiros \\ Apelados: Village dos Oitis Comercial Ltda. e Agora Sênior Corretora de \\ Títulos e Valores Mobiliários S.A. \\ Relatora: Des. Denise Levy Tredler \\ C.R.: 5
}

Apelação Cível. Pedido de rescisão contratual com restituição de $70 \%$ dos valores pagos. Contrato de compra e venda de imóvel com cláusula de alienação fiduciária. Inexistência de simulação ou de abusividade. Sentença que extingue o processo em relação ao primeiro réu e de improcedência em relação ao segundo, cuja manutenção se impõe. Desprovimento do recurso.

(...) Correta a sentença, que julgou extinto o processo sem análise do mérito, por ilegitimidade passiva do primeiro apelado, o qual, comprovadamente, realizou uma cessão de créditos relativos ao contrato em referência, por meio de emissão privada de cédulas de crédito

\footnotetext{
${ }^{74}$ CHALHUB, Melhim Namem. Negócio Fiduciário, p. 227.

${ }^{75}$ O fiduciário cedente exonerar-se-á de suas obrigações, salvo se, no contrato de cessão, for estabelecido que o cedente permanece responsável pela solvência do fiduciante. Não obstante, permanece o cedente obrigado perante o cessionário pela existência e validade do contrato e dos créditos dele decorrentes.
} 
imobiliário, ao segundo apelado, em estrita obediência às cláusulas contratuais.

Observe-se que a emissão das cédulas de crédito imobiliário transfere ao investidor todos os direitos inerentes à condição de credor do contrato originário. No caso em tela, o segundo apelado sub-rogou-se em todos os benefícios advindos do crédito adquirido, dentre eles todos aqueles decorrentes da alienação fiduciária em garantia, pelo que há ilegitimidade do credor originário do contrato de compra e venda ${ }^{76}$.

Para que a cessão seja realizada, é desnecessária a interpelação do fiduciante nas cessões de crédito listadas no artigo 35 da Lei $n^{\circ} 9.514$ de $1997^{77}$. Assim, busca a Lei "a simplificação e a celeridade dos negócios de cessão de crédito para funcionamento do mercado secundário de créditos imobiliários",78.

Salienta-se, adicionalmente, que é indispensável a averbação da cessão para que seja oponível a terceiros, inclusive ao fiduciante, uma vez que é pessoa alheia ao contrato de cessão. É através da averbação que o novo fiduciário torna-se formalmente investido dos seus direitos e legitimase à realização dos procedimentos de cobrança, de constituição do fiduciante em mora, de consolidação da propriedade em seu nome e da implementação da ação de reintegração de posse ${ }^{79}$.

No entanto, Renan Miguel Saad esclarece que na esteira da Súmula 84 do Superior Tribunal de Justiça ${ }^{80}$, o novo fiduciário, independentemente da averbação da cessão, já tem a posse e poderá valer-se dos interditos possessórios, assim como o é permitido nas promessas de compra e venda ${ }^{81}$.

Por oportuno, é importante destacar que também assume posição de fiduciário o fiador ou terceiro que pague a dívida, sub-rogando-se de pleno direito no crédito e na propriedade fiduciária, sujeitando-se às mesmas obrigações do fiduciário. Enfatiza Renan Miguel Saad que, tendo o

\footnotetext{
${ }^{76}$ TJRJ, Apelação Cível n ${ }^{\circ}$ 2007.001.64492, Rel. Desembargadora Denise Levy Tredler, Rio de Janeiro, 28 de janeiro de 2008.

${ }^{77}$ Art. 35. Nas cessões de crédito a que aludem os arts. $3^{\circ}, 18$ e 28 , é dispensada a notificação do devedor.

${ }^{78}$ CHALHUB, Melhim Namem. Negócio Fiduciário, p. 229.

${ }^{79}$ CHALHUB, Melhim Namem. Negócio Fiduciário, p. 228.

${ }^{80}$ Súmula 84. É admissível a oposição de embargos de terceiro fundados em alegação de posse advinda de compromisso de compra e venda de imóvel, ainda que desprovido do registro.

${ }^{81}$ SAAD, Renan Miguel. A alienação fiduciária sobre bens imóveis, p. 151.
} 
legislador usado a expressão "pagar dívida", ocorrerá sub-rogação apenas se o pagamento da dívida for total, ou seja, não vale para sub-rogação o pagamento de algumas prestações ${ }^{82}$.

\subsection{Cessão da posição do fiduciante}

\section{A Lei $n^{0} 9.514$ de 1997 também prevê a cessão da posição do} fiduciante nos seguintes termos:

Art. 29. O fiduciante, com anuência expressa do fiduciário, poderá transmitir os direitos de que seja titular sobre o imóvel objeto da alienação fiduciária em garantia, assumindo o adquirente as respectivas obrigações.

Nesse sentido, observa-se que a Lei menciona transmissão de direitos, pois o cedente-fiduciante é titular de um direito expectativo real ${ }^{83}{ }^{84}$ Corrobora Melhim Namem Chalhub ao dizer que "a implementação desse direito decorrerá do cumprimento das obrigações do fiduciante e do cancelamento da propriedade fiduciária, nos termos do artigo 25"85. Seria, portanto, impróprio afirmar que a cessão opera a transmissão da alienação fiduciária em garantia imobiliária ${ }^{86}$.

\footnotetext{
${ }^{82}$ SAAD, Renan Miguel. A alienação fiduciária sobre bens imóveis, p. 153.

${ }^{83}$ Orlando Gomes, citado por Renan Miguel Saad, ensina que "cedendo a terceiro a sua posição contratual, o financiado elimina voluntariamente a possibilidade de vir a ser dono do bem que adquiriu e alienou para garantir a dívida contraída para adquiri-lo. Se transferem os direitos e obrigações, passa, com a transferência à expectativa”.(SAAD, Renan Miguel. A alienação fiduciária sobre bens imóveis, p. 158.).

84 Ainda de acordo com Orlando Gomes, "as expectativas são direitos em formação, que dependem de um fato, ou de uma seqüência de fatos para se cumprirem. O consumidor, que aliena fiduciariamente o bem para garantir a dívida, tem, com efeito, um direito, pertencente atualmente a outro sujeito, mas que lhe deve ser transferido quando se verifique o pagamento da dívida, reingressando no seu patrimônio. (...) Entendido que se trata de um direito em formação, a expectativa do fiduciante, subordinada como se acha a uma condição potestativa, é transferível, inclusive por sucessão hereditária. Por sua natureza, pertence a seu patrimônio, nele se inscrevendo como um direito de apropriação através de cujo exercício o fiduciante realiza a expectativa. Assim, ao ceder sua posição contratual, transmite, igualmente, a expectativa, o direito eventual de se apropriar do que lhe passa a pertencer com o implemento da condição". (GOMES, Orlando. Alienação Fiduciária em Garantia. $3^{\mathrm{a}}$ ed. São Paulo: Editora Revista dos Tribunais, 1972. p. 144.).

${ }^{85}$ CHALHUB, Melhim Namem. Negócio Fiduciário, p. 230.

${ }^{86}$ LIMA, Frederico Henrique Viegas de. Da alienação fiduciária em garantia de coisa imóvel, p. 138.
} 
Diferentemente do que ocorre na cessão do fiduciário, a Lei, além de não excepcionar a interpelação do fiduciário em algumas situações, impõe expressamente que o mesmo intervenha na cessão da posição do fiduciante. Sub-rogando-se o cessionário nos direitos e obrigações do cedente, não pode a cessão de débito piorar a situação do credor na relação obrigacional, sendo ele o único juiz de sua conveniência ${ }^{87}$. Nesse sentido, aplica-se a regra geral de cessão presente no Código Civil, no qual a cessão sem anuência do fiduciário só produz efeito entre o cedente e o cessionário, tal como ocorre na cessão do fiduciário, não sendo caso excepcionado pelo artigo 35 da Lei n ${ }^{\circ} 9.514$ de 1997.

Ademais, é indispensável também o registro do contrato de cessão no Registro Geral de Imóveis, pois se trata de transmissão de direito real sobre imóvel. Salienta Melhim Namem Chalhub que

o interesse pelo assentamento da cessão no Registro de Imóveis é de ambas as partes, fiduciário e novo fiduciante, pois o cancelamento da propriedade fiduciária beneficiará aquele que figurar como fiduciante no Registro e, não havendo a averbação da cessão, continuará figurando o antigo fiduciante; de outra parte, na hipótese de mora do devedor, não poderá haver discrepância entre o nome que figurar do requerimento de intimação, formulado pelo fiduciário, e o nome que estiver constando do Registro, como titular dos direitos e obrigações do contrato ${ }^{88}$.

\subsubsection{Requisitos Objetivos}

O objeto da alienação fiduciária de imóveis é a propriedade temporária de coisa imóvel conforme o artigo 22 da Lei n ${ }^{\circ} 9.514$ de 1997. De acordo com o explicitado no capítulo anterior, o imóvel necessita ser passível de alienação, sendo, portanto, vedada a utilização de imóvel gravado com alguma cláusula de inalienabilidade.

Apesar de o objeto da referida garantia ser de fácil entendimento, suas especificidades sofreram inúmeras alterações desde a publicação da Lei ${ }^{0} 9.514$ de 1997.

\footnotetext{
${ }^{87}$ TJRJ, Apelação Cível $\mathrm{n}^{\circ}$ 1.509/97, Rel. Desembargador Laerson Mauro, Rio de Janeiro, 05 de junho de 1997. (SAAD, Renan Miguel. A alienação fiduciária sobre bens imóveis, p. 156.).

${ }^{88}$ CHALHUB, Melhim Namem. Negócio Fiduciário, p. 231.
} 
A redação original do parágrafo único do artigo 22 dispunha que poderia ser objeto de alienação fiduciária imobiliária a coisa imóvel concluída ou em construção. Resultou desta redação a discussão acerca de esta particularização servir como limitação ao objeto da garantia ou apenas fonte de esclarecimento sobre o objeto.

Para Melhim Namem Chalhub, servia como fonte de esclarecimento sobre o objeto, sendo mesmo assim, tecnicamente incorreta, uma vez que, tendo o caput definido o objeto como propriedade resolúvel de coisa imóvel, não há dúvida que este engloba o terreno e suas acessões, sendo, portanto, totalmente dispensável a particularização do parágrafo único. ${ }^{89}$ Este entendimento é corroborado pelo Código Civil de $2002^{90}$, como também o fazia o Código Civil de $1916^{91}$, através da definição de bem imóvel.

Por outro lado, para Frederico Henrique Viegas de Lima, o parágrafo único do artigo 22 da Lei $\mathrm{n}^{\circ} 9.514$ de 1997 servia como limitação do objeto da garantia, restando vedada sua utilização aos terrenos sem construção ${ }^{92}$.

Independentemente da posição que se resolva adotar, a discussão foi apaziguada através da alteração promovida pela Lei $\mathrm{n}^{\mathrm{0}} 10.931$ de 2.004 , a qual retirou a particularização do parágrafo único do artigo 22. Ademais, aproveitou para aclarar também outra questão, qual seja, a possibilidade de bem enfitêutico poder ser objeto da alienação fiduciária em garantia imobiliária, pois permitiu expressamente o uso deste contrato na hipótese mencionada.

Por fim, o parágrafo único do artigo 22 da Lei $\mathrm{n}^{\circ} 9.514$ de 1997, sofreu sua drástica alteração em 2007 promovida pela Lei ${ }^{\circ} 11.481$, de

\footnotetext{
${ }^{89}$ CHALHUB, Melhim Namem. Negócio Fiduciário, p. 206.

${ }^{90}$ Art. 79. São bens imóveis o solo e tudo quanto se lhe incorporar natural ou artificialmente,

${ }^{91}$ Art. 43. São bens imóveis:

I - o solo com sua superfície, os seus acessórios e adjacências naturais, compreendendo as árvores e frutos pendentes, o espaço aéreo e o subsolo;

II - tudo quanto o homem incorporar permanentemente ao solo, como a semente lançada à terra, $\underline{\mathbf{o s}}$ edifícios e as construcões, de modo que se não possa retirar sem modificação, fratura ou sano; (...) (grifo nosso).

${ }_{92}$ LIMA, Frederico Henrique Viegas de. Da alienação fiduciária em garantia de coisa imóvel, p. 88.
} 
2007. A mudança foi radical. Suprimiu-se o parágrafo único para que se acrescentassem dois parágrafos em seu lugar. Estes parágrafos pulverizaram também a discussão acerca da possibilidade de imóveis contendo algum gravame real serem objeto da garantia ${ }^{93}$. Reproduz-se a seguir, finalmente, em quadro comparativo, o artigo 22 da Lei de alienação fiduciária com sua redação original e atual:

\begin{tabular}{|c|c|}
\hline \multicolumn{2}{|c|}{ Art. 22 da Lei $n^{\circ} 9.514$ de 1997} \\
\hline Redação original & Redação atual \\
\hline $\begin{array}{l}\text { Art. } 22 \text { A alienação fiduciária regulada por } \\
\text { esta Lei é o negócio jurídico pelo qual o } \\
\text { devedor, ou fiduciante, com o escopo de } \\
\text { garantia, contrata a transferência ao credor, } \\
\text { ou fiduciário, da propriedade resolúvel de } \\
\text { coisa imóvel. } \\
\text { Parágrafo único. A alienação fiduciária } \\
\text { poderá ser contratada por pessoa física ou } \\
\text { jurídica, podendo ter como objeto imóvel } \\
\text { concluído ou em construção, não sendo } \\
\text { privativa das entidades que operam no SFI. }\end{array}$ & $\begin{array}{l}\text { Art. 22. A alienação fiduciária regulada por } \\
\text { esta Lei é o negócio jurídico pelo qual o } \\
\text { devedor, ou fiduciante, com o escopo de } \\
\text { garantia, contrata a transferência ao credor, } \\
\text { ou fiduciário, da propriedade resolúvel de } \\
\text { coisa imóvel. } \\
\S 1^{\circ} \text { A alienação fiduciária poderá ser } \\
\text { contratada por pessoa física ou jurídica, } \\
\text { não sendo privativa das entidades que } \\
\text { operam no SFI, podendo ter como objeto, } \\
\text { além da propriedade fiduciária plena: } \\
\text { I - bens enfitêuticos, hipótese em que será } \\
\text { exigível o pagamento do laudêmio, se } \\
\text { houver a consolidação do domínio útil no } \\
\text { fiduciário; } \\
\text { II - o direito de uso especial para fins de } \\
\text { moradia; } \\
\text { III - o direito real de uso, desde que } \\
\text { suscetível de alienação; } \\
\text { IV - a propriedade superficiária. } \\
\S 2^{\circ} \text { Os direitos de garantia instituídos nas } \\
\text { hipóteses dos incisos III e IV do } 1^{\circ} \text { deste } \\
\text { artigo ficam limitados à duração da } \\
\text { concessão ou direito de superfície, caso } \\
\text { também tenham sido transferidos por } \\
\text { período determinado. }\end{array}$ \\
\hline
\end{tabular}

Portanto, pode-se perceber que a redação atual alarga os bens que podem sujeitar-se à alienação fiduciária em garantia para incluir também outros direitos reais imobiliários, aumentando, desta forma, o campo de

\footnotetext{
${ }^{93}$ Melhim Namem Chalhub, antes da Lei n ${ }^{\circ} 11.481$ de 2.007, afirmava que este tipo de imóvel não deveria ter utilização prática, pois o gravame poderá neutralizar os efeitos de garantia pretendidos pelo credor. (CHALHUB, Melhim Namem. Negócio Fiduciário, pp. 207-208.).
} 
atuação deste instituto e fomentando o mercado de crédito imobiliário nacional.

\subsubsection{Requisitos Formais}

É indispensável ao contrato de alienação fiduciária imobiliária seu registro no Registro Geral de Imóveis, a fim de que seja constituído o direito real em garantia, no caso, a propriedade fiduciária imobiliária (artigo 23 da Lei $n^{0} 9.514$ de 1997). Pendente de registro, como já visto, não se pode falar em propriedade fiduciária.

No entanto, é preciso conhecer os requisitos formais do contrato em tela no que tange a dois pontos: conteúdo e forma.

\subsection{Cláusulas Essenciais}

A respeito do conteúdo do contrato, é necessário que o mesmo contenha ao menos conteúdo mínimo essencial e indispensável para que possa ser registrado, pois se trata de contrato típico. Sendo a alienação fiduciária em garantia de bem imóvel regulada pela Lei n ${ }^{0} 9.514$ de 1997 e não pelo Código Civil, é aquela que define as cláusulas necessárias, embora algumas sejam previstas em ambas as leis. São elas:

Art. $24 \mathrm{O}$ contrato que serve de título ao negócio fiduciário conterá: I - o valor do principal da dívida;

II - o prazo e as condições de reposição do empréstimo ou do crédito do fiduciário

III - a taxa de juros e os encargos incidentes;

IV - a cláusula de constituição da propriedade fiduciária, com a descrição do imóvel objeto da alienação fiduciária e a indicação do título de aquisição;

$\mathrm{V}$ - a cláusula assegurando ao fiduciante enquanto inadimplente a livre utilização, por sua conta e risco, do imóvel objeto da alienação fiduciária; VI - a indicação, para efeito de venda em público leilão, do valor do imóvel e dos critérios para a respectiva revisão;

VII - a cláusula dispondo sobre os procedimentos de que trata o art. 27. (grifo nosso) 
Nesse sentido, apenas poderão ser registrados os contratos em que contiverem ao menos as cláusulas supracitadas. Como bem ressalta Renan Miguel Saad, "não quer dizer que o oficial do registro irá adentrar no conteúdo das aludidas cláusulas, haja vista que, em relação a estas, valerá a autonomia da vontade, limitada sim pelas normas gerais de nosso direito" ${ }^{\text {" }}$.

Portanto, pelo princípio da autonomia da vontade, podem as partes acrescentar ao contrato outras cláusulas para particularizar situações específicas $^{95}$. O que não podem fazer é alterar o conteúdo das cláusulas enumeradas essenciais ou ainda excluir cláusula ou outra, por serem as mesmas imperativas e cogentes.

Ao analisarem-se as cláusulas essenciais do contrato de alienação fiduciária em garantia de bem imóvel, percebe-se que a lei buscou, igualmente ao que ocorre na hipoteca, criar um instituto que concilie um duplo interesse, isto é, "um negócio jurídico de garantia que permita a existência do assenhoramento pelo credor do bem objeto da mesma, sem, contudo, privar o devedor da sua utilização" ${ }^{\text {"96 }}$.

A primeira cláusula essencial refere-se ao valor principal da dívida a ser expresso em moeda corrente brasileira. Em seguida, tem-se a necessidade de fixação do prazo da contratação, pois é vedada a propriedade fiduciária perpétua. e da fixação da periodicidade do pagamento das prestações.

Adiante, vislumbra-se imperiosa a indicação da taxa de juros e encargos incidentes. Neste aspecto, é preciso atentar ao fato de que o artigo $5^{\circ}$, III da Lei ${ }^{0} 9.514$ de $1997^{97}$ permite a capitalização dos juros nos contratos de alienação fiduciária imobiliária. Esta permissão, entretanto,

\footnotetext{
${ }^{94}$ SAAD, Renan Miguel. A alienação fiduciária sobre bens imóveis, p. 164.

${ }^{95}$ Frederico Henrique Viegas de Lima classifica o conteúdo necessário do contrato como essentialia negotti, e as cláusulas que complementar o conteúdo mínimo de accidentalia negotti. (LIMA, Frederico Henrique Viegas de. Da alienação fiduciária em garantia de coisa imóvel, p. 108.).

${ }^{96}$ LIMA, Frederico Henrique Viegas de. Da alienação fiduciária em garantia de coisa imóvel, p. 110.

${ }^{97}$ Art. $5^{\circ}$ As operações de financiamento imobiliário em geral, no âmbito do SFI, serão livremente pactuadas pelas partes, observadas as seguintes condições essenciais:

III - capitalização dos juros.
} 
somente se aplica às entidades autorizadas a funcionar no Sistema de Financiamento Imobiliário. Frederico Henrique Viegas de Lima aponta que a permissão legal do referido artigo afasta o contrato em tela da vedação da Súmula $121^{98}$ do Supremo Tribunal Federal e inclui a contratação nas exceções da Súmula $596^{99}$ do Supremo Tribunal Federal nos casos em que figura como credora uma entidade autorizada a funcionar no Sistema de Financiamento Imobiliário.

Alerta o referido jurista que, nos casos em que o fiduciário é pessoa não autorizada a capitalizar os juros, não vigorará a permissão. São suas palavras:

Neste particular, deve-se fazer a distinção entre a contratação em que figure como credora fiduciária uma entidade autorizada a funcionar dentro do Sistema de Financiamento Imobiliário e nos casos em que o credor seja uma entidade não autorizada ou um particular. A possibilidade de incidência de juros capitalizados, bem como a utilização de taxas de juros do mercado financeiro, só pode ser empregada pelas instituições financeiras ou entidades que operam no Sistema de Financiamento Imobiliário. É impensável que o particular, embora credor fiduciário, possa valer-se da excepcionalidade, quer da Lei $\mathrm{n}^{\circ} 9.514$ de 1997, quer da Súmula 596 do Supremo Tribunal Federal ${ }^{100}$.

Prosseguindo, tem-se por necessária a disposição sobre a constituição do direito real de garantia, isto é, da propriedade fiduciária, após o registro do contrato. Nesse diapasão, devedor ou terceiro interveniente declarará expressamente seu desejo de transferir o bem imóvel com escopo de garantia pelo prazo pactuado ${ }^{101}$. Por outro lado, o credor deverá manifestar-se pela aceitação do bem.

Pelo princípio da individualização das garantias, regra das garantias reais, é mister a identificação do bem imóvel sobre o qual recairá a

\footnotetext{
${ }^{98}$ Súmula 121 - É vedada a capitalização de juros, ainda que expressamente convencionada.

${ }^{99}$ Súmula 596 - As disposições do decreto 22.626/1933 não se aplicam às taxas de juros e aos outros encargos cobrados nas operações realizadas por instituições públicas ou privadas, que integram o Sistema Financeiro Nacional.

${ }^{100}$ LIMA, Frederico Henrique Viegas de. Da alienação fiduciária em garantia de coisa imóvel, pp. 112-113.

${ }^{101}$ Conforme Mario Pazutti Mezzari, a cláusula deve ser expressa, não sendo suficiente, por exemplo, a simples referência no título do contrato. (MEZZARI, Mario Pazutti. Alienação Fiduciária da Lei n. 9.514, de 20-11-1997, p. 40.).
} 
propriedade fiduciária, bem como do título e do modo da aquisição ${ }^{102}$. Tal exigência repete as normas contidas nos artigos 176, § $1^{\circ}$, II e 225 ambos da Lei $\mathrm{n}^{\circ} 6.015$ de 1973, que trata dos registros públicos.

Ademais, exige-se cláusula que permita a livre utilização do imóvel pelo devedor adimplente, por sua conta e risco. Esta cláusula resulta do desdobramento da posse previsto no artigo 23 da Lei $n^{0} 9.514$ de 1997, cabendo ao devedor fiduciante a posse direta e ao fiduciário a indireta. Além disso, é norma que tem o condão de proteger credor e devedor. Aquele é protegido, uma vez que ao devedor só lhe é conferido o direito de livre utilização enquanto permanecer adimplente, isto é, enquanto sua posse for justa, pois caso se torne inadimplente, sua posse se transforma em precária. Ademais, é consignado ao devedor não apenas o direito de usar, mas também os seus encargos. Já o devedor é protegido, tendo em vista que pró́be a interferência do credor na posse do devedor, seja na modalidade de esbulho ou turbação ${ }^{103}$.

Ainda no conteúdo mínimo do contrato de alienação fiduciária imobiliária, há comando de cláusula para indicar o preço do imóvel caso o mesmo seja objeto de eventual público leilão ${ }^{104}$, bem como os critérios para revisão de tal valor. Ressalta-se que, igualmente ao que ocorre na hipoteca, o preço do imóvel funciona como uma avaliação prévia, não precisa guardar relação com o valor da obrigação principal, sendo possível que ultrapasse o valor da dívida. No entanto, sendo o bem vendido por valor

\footnotetext{
${ }^{102}$ Segundo Mario Pazutti Mezzari, a redação da Lei referente a modo e título é anacrônica, pois o sistema brasileiro prevê o registro como constitutivo de direito, eficaz entre partes e contra terceiros. O modo, nesse sistema, é tão decisivo que absorve o título. Aqui o título não constitui direito, ainda que, em torno dele, haja acordo de vontades. Completa ainda dizendo que, na verdade, bastante será, para atender ao disposto neste inciso IV do art. 24 da Lei n. 9.514/97, que se faça expressa referência à matrícula ou ao registro anterior, seu número e cartório, como exigido na Lei dos Registros Públicos, art. 222. (MEZZARI, Mario Pazutti. Alienação Fiduciária da Lei $n$. 9.514, de 20-11-1997, pp. 42-43.).

${ }^{103}$ Vale dizer que neste caso, também são invocados os artigos 1.197 do Código Civil - A posse direta, de pessoa que tem a coisa em seu poder, temporariamente, em virtude de direito pessoal, ou real, não anula a indireta, de quem aquela foi havida, podendo o possuidor direto defender a sua posse contra o indireto; e $1.210 \S 2^{\circ}$ - Não obsta à manutenção ou reintegração na posse a alegação de propriedade, ou de outro direito sobre a coisa.

${ }^{104}$ É por este valor, e por nenhum outro, que o imóvel será levado ao primeiro público leilão.
} 
superior à dívida, caberá ao credor entregar ao devedor o valor excedente, sob pena de enriquecimento sem causa.

No tocante aos critérios para revisão do valor, os mesmos têm por finalidade a atualização do preço, evitando que fique defasado com o decurso do tempo. Destaca-se que, as partes não podem alterar o preço do imóvel após sua indicação no contrato, apenas podem indicar neste instrumento os critérios de atualização. A razão para tal vedação é garantir a celeridade e a agilidade da eventual alienação do imóvel através de público leilão. Explica Frederico Henrique Viegas de Lima que:

Não seria concebível que as partes, uma vez convencionado o valor do
bem para a finalidade de sua venda pública, alterassem o seu valor. Deste
modo, estaria sendo feita letra morta do citado inciso VI, do artigo 24 , da
Lei $\mathrm{n}^{\circ} 9.514$ de 1997 , uma vez que, sendo possível o reajuste do preço,
nada mais é que uma avaliação no momento em que se realiza a venda. A
finalidade do estabelecimento do valor do bem é evitar sua futura
avaliação ${ }^{105}$.

Por fim, para completar o conteúdo mínimo legal, há a cláusula na qual as partes necessitam estabelecer o procedimento do público leilão que será utilizado caso o devedor fiduciante se torne inadimplente ${ }^{106}$. Este procedimento, no entanto, não é de livre convenção das partes, pois a própria lei faz suas exigências no artigo 27. Por exemplo, é obrigatória a alienação do bem pelo credor, caso a propriedade fiduciária seja consolidada em seu nome. A lei estipula o prazo de 30 (trinta) dias para a referida alienação, sendo, entretanto, inexistente qualquer tipo de sanção pelo descumprimento do prazo. O que as partes podem livremente dispor é a forma de alienação do bem, se a mesma ocorrerá através de venda judicial ou extrajudicial, isto é, com ou sem a intervenção do Poder Judiciário.

O contrato precisa ainda conter cláusula relativa ao prazo de carência para expedição da intimação da mora presente no artigo 26 da Lei $\mathrm{n}^{\circ} 9.514$ de 1997 e transcrita a seguir:

${ }^{105}$ LIMA, Frederico Henrique Viegas de. Da alienação fiduciária em garantia de coisa imóvel, p. 117.

${ }^{106}$ Não obstante a letra da Lei, Mario Pazutti Mezzari afirma que é o capital quem dita as regras do contrato e não irá criar para si mais dificuldades do que aquelas que o legislador já lhe impõe. (MEZZARI, Mario Pazutti. Alienação Fiduciária da Lei n. 9.514, de 20-11-1997, p. 44.). 
Art. 26. Vencida e não paga, no todo ou em parte, a dívida e constituído em mora o fiduciante, consolidar-se-á, nos termos deste artigo, a propriedade do imóvel em nome do fiduciário.

$\S 2^{\circ}$. O contrato definirá o prazo de carência após o qual será expedida a intimação.

(grifo nosso)

De acordo com o referido artigo, o contrato deverá dispor sobre o prazo de tolerância durante o qual o credor suportará a inadimplência do devedor antes de ser expedida intimação da mora pelo Oficial do Registro de Imóveis. Apesar de este assunto ser essencial ao contrato de alienação fiduciária em garantia, a Lei não nulifica o contrato que não contenha esta cláusula, sendo a mesma chamada por Frederico Henrique Viegas de Lima de facultativa. Em nome da segurança jurídica, as partes devem dispor sobre o prazo de carência, pois é de interesse de ambas sua definição. Resume Mario Pazutti Mezzari:

A lei não comina de nulidade o contrato de alienação fiduciária que não tiver previsto esse prazo de carência. Nem parece que essa seja uma daquelas propaladas "normas de ordem pública", obrigatória, cogente, indescumprível. $\mathrm{Na}$ verdade, o grande risco de não consignar o prazo de carência será suportado exatamente pelo credor, que não saberá quando poderá começar o processo de execução contratual. Qualquer prazo que o credor adote, não previsto no contrato, poderá ser contestado pelo devedor, protelando-se assim um procedimento que nasceu para ser célere, o da rescisão contratual.

Bem se poderia afirmar que o devedor também estará inseguro quando não souber qual a tolerância do credor em relação à sua inadimplência, mas a legislação brasileira é pródiga em proteger o considerado mais fraco - o devedor -, e as práticas de mercado serão facilmente utilizadas por ele contra o credor $^{107}$.

Após a análise do conteúdo essencial do contrato de alienação fiduciária, é mister conhecer a forma que o mesmo revestirá.

\subsection{Requisitos de Forma}

Inicialmente, vale dizer que os negócios jurídicos para serem válidos no ordenamento jurídico pátrio precisam preencher os requisitos do artigo

${ }^{107}$ MEZZARI, Mario Pazutti. Alienação Fiduciária da Lei n. 9.514, de 20-11-1997, p. 45. 
104 do Código Civil, isto é, precisam possuir agente capaz; objeto lícito, possível, determinado ou determinável; e forma prescrita ou não defesa em lei. No que tange à forma, através da leitura do artigo 107 do Código Civil $^{108}$, percebe-se que o direito brasileiro consagra o princípio da liberdade das formas. Assim, não tendo a lei previsto forma específica, as partes podem celebrar o negócio na forma que desejarem. Em seguida, o artigo 108 do Código Civil ${ }^{109}$ preceitua que, em relação à constituição, transferência, modificação ou renúncia de direitos reais sobre imóveis de valor superior a 30 (trinta) vezes o salário mínimo vigente no País, o negócio jurídico deverá ser realizado em escritura pública, salvo disposição de lei em contrário.

Ao analisar-se a Lei $n^{0} 9.514$ de 1997 , percebe-se que seu artigo 38 prevê o seguinte:

Art. 38. Os atos e contratos referidos nesta Lei ou resultantes da sua aplicação, mesmo aqueles que visem à constituição, transferência, modificação ou renúncia de direitos reais sobre imóveis, poderão ser celebrados por escritura pública ou por instrumento particular com efeitos de escritura pública.

Nessa trilha, os contratos de alienação fiduciária imobiliária podem ser realizados de acordo com o artigo 108 do Código Civil, isto é, por escritura pública, ou ainda por instrumento particular com efeitos de escritura pública por expressa disposição legal.

Frise-se que a redação do referido artigo 38 sofreu algumas alterações e que nenhuma delas proibiu a possibilidade de se firmar o contrato por instrumento particular. A redação original do artigo previa que apenas os contratos celebrados com pessoa física, beneficiária da operação, poderiam ser formalizados por instrumento particular. Renan Miguel Saad, valendo-se do conceito de isonomia material, justifica o tratamento diferenciado promovido pela redação original do artigo 38 afirmando que

\footnotetext{
108 Art. 107. A validade da declaração de vontade não dependerá de forma especial, senão quando a lei expressamente a exigir.

109 Art. 108. Não dispondo a lei em contrário, a escritura pública pe essencial à validade dos negócios jurídicos que visem à constituição, transferência, modificação ou renúncia de direitos reais sobre imóveis de valor superior a 30 (trinta) vezes o maior salário mínimo vigente no País.
} 
“o dispositivo consagra comando à redução dos custos para a pessoa natural, aceitando que se celebrem os respectivos contratos por instrumento particular" ${ }^{\prime 10}$.

Após tamanha discussão sobre a prerrogativa de somente pessoas físicas poderem formalizar a contratação por instrumento particular, foi editada a Medida Provisória $n^{0} 2.223$ de 2001, que alterou a redação do artigo 38 da Lei $n^{\circ} 9.514$ de 1997 , para permitir que qualquer pessoa, seja física ou jurídica, possa realizar a contratação por instrumento particular com efeitos de escritura pública.

Finalmente, o referido artigo passou por novas alterações, tendo atualmente redação dada pela Lei $\mathrm{n}^{\mathrm{o}} 11.076$ de 2004 que manteve a permissão genérica para utilização do instrumento particular com força de escritura pública para contratação.

\subsubsection{Extinção do contrato}

Depois de vistos as características da propriedade fiduciária imobiliária e os requisitos para formação do contrato entre fiduciário e fiduciante, é preciso conhecer suas formas de extinção. São duas: pelo adimplemento ou inadimplemento do fiduciante em relação à obrigação principal contratada, isto é, pelo pagamento integral ou não da dívida.

\subsubsection{Pelo adimplemento do fiduciante}

A extinção do contrato pelo adimplemento do devedor se dá pelo pagamento da dívida pelo fiduciante. É a principal forma de extinção da alienação fiduciária em garantia, pois devedor e credor no momento em que acordam pela celebração do contrato, devem estar eivados de boa-fé e, por isso, esperam que o contrato extinga-se naturalmente pelo cumprimento do pactuado.

${ }^{110}$ SAAD, Renan Miguel. A alienação fiduciária sobre bens imóveis, p. 165. 
Considerando-se que a transmissão da propriedade imobiliária ocorreu com escopo de garantir outra obrigação, estando esta paga, resolvese a propriedade fiduciária imobiliária em favor do credor para seu retorno ao patrimônio do devedor. O pagamento opera, portanto, o implemento da condição que, por um lado, obriga o fiduciário a dar quitação ao fiduciante e, por outro, possibilita que este recupere a plena propriedade do imóvel ${ }^{111}$.

Acerca do adimplemento contratual, dispõe o artigo 25 da Lei $n^{\circ}$ 9.514 de 1997:

Art. 25. Com o pagamento da dívida e seus encargos, resolve-se, nos termos deste artigo, a propriedade fiduciária do imóvel.

$\$ 1^{\circ}$ No prazo de trinta dias, a contar da data de liquidação da dívida, o fiduciário fornecerá o respectivo termo de quitação ao fiduciante, sob pena de multa em favor deste, equivalente a meio por cento ao mês, ou fração, sobre o valor do contrato.

$\$ 2^{\circ}$ À vista do termo de quitação de que trata o parágrafo anterior, o oficial do competente Registro de Imóveis efetuará o cancelamento do registro da propriedade fiduciária.

Assim, com o pagamento da obrigação principal, o credor tem a obrigação de em trinta dias fornecer o termo de quitação ao fiduciante sob pena de multa de meio por cento ao mês (ou fração ${ }^{112}$ ) para que o mesmo proceda ao cancelamento do registro da propriedade fiduciária.

É válido lembrar que, sobre o pagamento, aplicam-se os princípios gerais previstos nos artigos 304 e seguintes do Código Civil, bem como a regra do artigo 31 da Lei $n^{0} 9.514$ de $1997^{113}$ sobre a sub-rogação do fiador ou do terceiro interessado que pague integralmente a dívida.

Em relação ao termo de quitação, Renan Miguel Saad o conceitua como

o instrumento capaz de gerar validamente a obrigação de transferência do domínio, na medida em que, diante do termo de quitação, a propriedade deixa de ser resolúvel e de pertencer ao fiduciário para se tornar plena e sob o domínio do fiduciante. ${ }^{114}$

${ }^{111}$ CHALHUB, Melhim Namem. Negócio Fiduciário, p. 214.

${ }^{112}$ Neste caso, ou seja, a mora do credor seja inferior a trinta dias, o cálculo será feito pro rata die.

${ }^{113}$ Art. 31. O fiador ou terceiro interessado que pagar a dívida ficará sub-rogado, de pleno direito, no crédito e na propriedade fiduciária.

${ }^{114}$ SAAD, Renan Miguel. A alienação fiduciária sobre bens imóveis, p. 199. 
O documento será fornecido pelo fiduciário ao fiduciante, permitindo o cancelamento da propriedade fiduciária no Registro Geral de Imóveis, fazendo com que o fiduciante tenha novamente a propriedade plena do imóvel. Esse cancelamento gera o imediato retorno da situação jurídicodominial do bem ao status quo ante, uma vez que o devedor volta a ser titular do mesmo direito de propriedade que tinha antes de realizar a alienação fiduciária ${ }^{115}$. Entretanto, caso ao longo da existência do contrato tenha ocorrido a cessão da posição do fiduciante, não se pode falar em retorno da situação jurídico-dominial anterior, pois o cessionário jamais foi proprietário do imóvel, mas sim era apenas titular de um direito expectativo real.

No que tange aos efeitos do cancelamento, os mesmo são ex tunc, em outras palavras, retroagem à data da constituição da propriedade fiduciária. Sobre o tema, complementa Frederico Henrique Viegas de Lima ao afirmar que "todos os direitos ou ônus porventura estabelecidos sobre a propriedade fiduciária desaparecem a partir do cancelamento, e o retorno da propriedade é efetuado sem a incidência de nenhum gravame. ${ }^{116}$

Em conclusão, pode-se perceber que o sistema disposto no $\S 2^{\circ}$ do artigo 25 da Lei n ${ }^{\circ} 9.514$ de 1997, ou seja, de baixa da alienação fiduciária mediante a apresentação do termo, simplifica a vida do fiduciante ao comparar-se ao contrato de promessa de compra e venda, que necessita da feitura de escritura definitiva de compra e venda, cabendo, na recusa do promitente vendedor, o requerimento judicial da adjudicação compulsória pelo comprador, conforme norma contida no artigo 1.418 do Código Civil ${ }^{117}$. Aclara Mario Pazutti Mezzari que, em ambos os procedimentos (escritura definitiva ou adjudicação compulsória), há custos elevados e, no

\footnotetext{
${ }^{115}$ MEZZARI, Mario Pazutti. Alienação Fiduciária da Lei n. 9.514, de 20-11-1997, p. 59.

${ }^{116}$ LIMA, Frederico Henrique Viegas de. Da alienação fiduciária em garantia de coisa imóvel, p. 126.

${ }^{117}$ Art. 1.418. O promitente comprador, titular de direito real, pode exigir do promitente vendedor, ou de terceiros, a quem os direitos deste forem cedidos, a outorga da escritura definitiva de compra e venda, conforme o disposto no instrumento preliminar; e, se houver recusa, requerer ao juiz a adjudicação do imóvel.
} 
último, há tempo de execução dilatado, pois é necessária a intervenção do Poder Judiciário $^{118}$.

\subsubsection{Pelo inadimplemento do fiduciante}

A responsabilidade pela inadimplência funciona como incentivo ao bom desempenho do contrato $^{119}$. Assim, a outra forma de extinção do contrato de alienação fiduciária se configura pelo inadimplemento do fiduciante em relação à obrigação principal.

Dispõe o artigo 26 da Lei $n^{0} 9.514$ de $1997^{120}$ que, deixando o fiduciante de pagar a dívida, deverá ser constituído em mora nos termos da lei em referência. Após este período, caso o devedor continue inadimplente, será rompido o contrato e haverá a consolidação da propriedade fiduciária em favor do fiduciário. Conforme se pode perceber, o procedimento criado pela Lei $n^{0} 9.514$ de 1997 visa à celeridade na execução do crédito do fiduciário, reduzindo o risco para o credor e facilitando o acesso ao crédito imobiliário para o devedor. Dessa forma, são as palavras de Eduardo Takemi, citado por Cristiano Chaves de Farias e Nelson Rosenvald:

A grande facilitação da retomada e consolidação da propriedade do imóvel pelo credor em caso de inadimplemento, inclusive com a dispensa do processo - ao contrário da lenta execução que ocorre no sistema hipotecário -, torna-se um fator de estímulo à construção civil, pois incita o financiador a buscar a atividade cujo risco é mitigado pelo ordenamento jurídico pela célere recuperação do crédito. reflexamente, esta confiança conduzirá a uma redução nas taxas de juros, muito influenciadas pelo fator de risco ${ }^{121}$.

Além do descumprimento da obrigação principal - o pagamento da dívida - outras obrigações também ensejam a ruptura do contrato. A exemplo, podem ser citadas três causas de vencimento antecipado, sendo algumas previstas também no Código Civil.

\footnotetext{
${ }^{118}$ MEZZARI, Mario Pazutti. Alienação Fiduciária da Lei n. 9.514, de 20-11-1997, p. 60.

${ }^{119}$ PINHEIRO \& SADDI. Direito, Economia e Mercados. p. 133.

${ }^{120}$ Art. 26. Vencida e não paga, no todo ou em parte, a dívida e constituído em mora o fiduciante, consolidar-se-á, nos termos deste artigo, a propriedade do imóvel em nome do fiduciário.

${ }^{121}$ TAKEMI, Eduardo. Notas sobre a Alienação Fiduciária de Bens Imóveis, p. 166. apud FARIAS \& ROSENVALD. Direitos Reais, p. 387.
} 
A primeira delas é a ocorrência de deterioração do imóvel, desfalcando a garantia do credor. Alerta-se que, diferentemente do que prega o Código Civil no tocante às regras gerais dos direitos reais de garantia, na propriedade fiduciária imobiliária não é possível a substituição do objeto ou o reforço da garantia. Ensina Frederico Henrique Viegas de Lima, que

o bem, durante a pendência da obrigação principal, pertence, em propriedade fiduciária resolúvel, ao credor fiduciário, razão pela qual não é próprio do negócio jurídico efetuado que possa o devedor fiduciante reforçar a garantia ou mesmo substituir o seu objeto. Caso existisse esta possibilidade, em realidade teríamos a extinção da propriedade fiduciária, com a conseqüente extinção do direito real ${ }^{122}$.

A segunda causa é a insolvência do devedor (artigo 32 da Lei $\mathrm{n}^{\circ}$ 9.514 de 1997 e artigo 1.425 do Código Civil) que assegura ao credor o direito de requerer a restituição do imóvel alienado fiduciariamente.

Já a terceira causa é a desapropriação do imóvel dado em garantia (artigo 1.425 inciso V do Código Civil). Nesta situação, credor e devedor serão chamados ao processo, e todos os direitos que recaírem sobre o imóvel se sub-rogam no preço. Em virtude dessa sub-rogação, por força de lei, será consignado em favor do credor-fiduciário o valor necessário para seu integral pagamento. Se o valor for superior, caberá o que sobejar ao devedor-fiduciante ${ }^{123}$.

Retornando ao descumprimento da obrigação principal, conforme afirmado, o devedor inadimplente deverá ser constituído em mora, sendolhe assegurado prazo para efetuar o pagamento. Caso deixe de purgar a mora, caberá ao credor o exercício do direito de satisfação do crédito através da consolidação da propriedade do bem imóvel em seu nome.

Por partes, aborda-se inicialmente a constituição da mora do fiduciante. De acordo com o Código Civil, a mora é caracterizada simplesmente pelo não pagamento no tempo, modo e lugar convencionado.

${ }^{122}$ LIMA, Frederico Henrique Viegas de. Da alienação fiduciária em garantia de coisa imóvel, p. 127.

${ }^{123}$ DANTZGER, Afrânio Carlos Camargo. Alienação Fiduciária de Bens Imóveis, p. 81. 
Entretanto, a Lei $\mathrm{n}^{\circ} 9.514$ de 1997, a fim de evitar que o fiduciante seja surpreendido com a subtração repentina do imóvel ${ }^{124}$, preceitua a obrigatoriedade da constituição do devedor em mora através de uma intimação, que deverá ser expedida depois de esgotado o prazo de carência estabelecido contratualmente pelas partes (artigo $26 \S^{\circ}$ da Lei ${ }^{\circ} 9.514$ de $1997^{125}$ ). Caso prazo algum tenha sido estipulado, a intimação pessoal do devedor para configuração da mora poderá ser efetuada tão logo se verifique a inadimplência ${ }^{126}$.

No que tange ao procedimento da intimação, conforme prevê a Lei n 9.514 de 1997, deverá o credor requerê-la expressamente, pois não é possível que proceda de ofício, e deverá ser realizada pelo oficial do competente Registro de Imóveis. Segundo os ensinamentos de Melhim Namem Chalhub, ao Oficial do Registro de Imóveis é facultada a realização direta da intimação ou a transmissão dessa diligência a um Oficial de Títulos e Documentos da comarca da situação do imóvel ou do domicílio de quem deva recebê-la ${ }^{127}$. Completa Mario Pazutti Mezzari que

Espera-se que poucos registradores de imóveis tomem a si o mister de efetuar a intimação, uma vez que não dispõem de funcionários treinados para essa tarefa (estranha ao cotidiano do Ofício Imobiliário), e, evidentemente, só em casos muito especiais o registrador de imóveis fará ele mesmo a intimação.

O que deve ocorrer é que, valendo-se da permissão legal contida no art. $26 \$ 3^{\circ}$, o oficial repasse o serviço ao Ofício do Registro de Títulos e Documentos, este sim, afeito a tais procedimentos. Aliás, tal repasse já é largamente utilizado nas intimações derivadas da aplicação da legislação sobre o parcelamento do solo urbano (...).

Nos casos em que o devedor residir em comarca diversa da de localização do imóvel, o oficial, se não optar pela intimação postal,

\footnotetext{
${ }^{124}$ Aproveitando as lições de Renan Miguel Saad, distingue-se a disciplina da alienação fiduciária de bens móveis e imóveis, no que se refere à inserção e importância da intimação do fiduciante para validação da mora. Isto porque, na alienação fiduciária de bem imóvel, há necessidade de constituição em mora do fiduciante, sendo a intimação o meio pelo qual a mesma se efetivará. Já na alienação fiduciária de bem móvel a mora constitui-se ex re, valendo a intimação como meio de sua prova. (SAAD, Renan Miguel. A alienação fiduciária sobre bens imóveis, p. 235.).

${ }^{125}$ Art. $26 \S 2^{\circ} \mathrm{O}$ contrato definirá o prazo de carência após o qual será expedida a intimação.

${ }^{126}$ No entanto, reitera-se a importância da definição do prazo de carência a fim de evitar a insegurança das partes conforme explicado anteriormente no ponto sobre as Cláusulas Essenciais.

${ }^{127}$ CHALHUB, Melhim Namem. Negócio Fiduciário, p. 214.
} 
certamente deverá encaminhar pedido ao Ofício do Registro de Títulos e Documentos daquela $^{128}$.

Ademais, é necessário dizer que a intimação deverá ser feita pessoalmente ao devedor ou ao seu procurador ou representante legal (artigo $26 \S 3^{\circ}$ da Lei $n^{\circ} 9.514$ de $1997^{129}$ ). No primeiro caso, vale ressaltar que, sendo o devedor casado, seu cônjuge, salvo no regime de separação absoluta, também deverá ser intimado, pois a intimação da mora pode levar à disposição do bem. Já no segundo, é procurador toda a pessoa que receber poderes específicos para receber essa espécie de intimação, uma vez que não se trata de mera administração de bens. No terceiro caso, é representante legal quem responde ativa ou passivamente pela pessoa jurídica de acordo com o estatuto social ${ }^{130}$.

Em qualquer dos três casos acima tratados, Melhim Namem Chalhub alerta que se a intimação for feita por Correio, apenas valerá se o aviso de recebimento for assinado pelo próprio devedor, seu procurador ou seu representante legal ${ }^{131132}$. Além da intimação postal, é possível que a intimação seja feita por edital ${ }^{133}$, desde que o fiduciante, seu procurador ou representante legal, encontrem-se em local incerto e não sabido.

${ }^{128}$ MEZZARI, Mario Pazutti. Alienação Fiduciária da Lei n. 9.514, de 20-11-1997, p. 63.

${ }^{129}$ Art. $26 \$ 3^{\circ}$ A intimação far-se-á pessoalmente ao fiduciante, ou ao seu representante legal ou ao procurador regularmente constituído, podendo ser promovida, por solicitação do oficial do Registro de Imóveis, por oficial de Registro de Títulos e Documentos da Comarca da situação do imóvel ou do domicílio de quem deva recebê-la, ou pelo correio com aviso de recebimento.

${ }^{130}$ Segundo observa Renan Miguel Saad, a jurisprudência nacional, ao tratar da citação - e em igual linha de raciocínio pode-se aplicar à intimação da Lei 9.714 de 1997-, diverge quanto à possibilidade de se dar eficácia ao ato processual, dando-a como válida a citação quando entregue, por exemplo, a um funcionário de determinada empresa que não tem poderes de representação ou à convivente de um devedor. Afirma que a orientação, tanto dos Tribunais de Justiça, quanto do STJ, não é cediça quanto à validade ou não nesses casos, ora aceitando a tese de eficácia do ato citatório, sob o argumento de que nesses casos aplicar-se-ia a teoria da aparência, ora afirmando que a teoria da aparência é inaplicável por se tratar de ato cuja formalidade é essencial para sua validade. (SAAD, Renan Miguel. A alienação fiduciária sobre bens imóveis, pp. 231 e 233.).

${ }^{131}$ CHALHUB, Melhim Namem. Negócio Fiduciário, p. 215.

${ }^{132}$ Em sentido contrário, Frederico Henrique Viegas de Lima repudia a viabilidade de intimação postal, uma vez que os Correios não efetuam a entrega de correspondência pessoalmente, sendo mais comum que sejam dadas a empregados e prepostos. Ademais, apresenta outro argumento ao dizer que somente é certificada a entrega da correspondência, faltando comprovação do conteúdo da mesma. (LIMA, Frederico Henrique Viegas de. Da alienação fiduciária em garantia de coisa imóvel, p. 130.).

${ }^{133} \mathrm{O}$ edital será realizado de acordo com o artigo $26 \$ 4^{\circ}$ da Lei $n^{\circ} 9.514$ de 1997, que dispõe: Art. $26 \S 4^{\circ}$ Quando o fiduciante, ou seu representante legal ou procurador regularmente constituído se encontrar em outro local, incerto e não sabido, o oficial certificará o fato, cabendo, então, ao 
Ademais, de acordo com ementas de julgados do Tribunal de Justiça do Rio de Janeiro, é possível também a intimação por hora certa, bem como o suprimento da intimação pelo reconhecimento da mora pelos devedores.

São respectivamente os dois julgados:

\author{
TRIBUNAL DE JUSTIÇA DO RIO DE JANEIRO \\ $10^{a}$ Câmara Cível \\ Agravo de Instrumento $n^{\circ}$ 2006.002.18991 \\ Agravante: Luiz Marcelo Peixoto Lubanco \\ Agravado: Jardins do Recreio Empreendimentos e Participações Ltda. \\ Relator: Des. José Carlos Varanda \\ C.R.: 5
}

Agravo Instrumental. Alienação Fiduciária em garantia de bem imóvel. Mora existente. Ação de reintegração de posse. Deferimento liminar. Acerto da decisão. Alegação de nulidade da notificação. Improcedência. Mais de 20 tentativas extrajudiciais e judiciais de se notificar pessoalmente o devedor. Correta a notificacão por hora certa. Manutenção da decisão agravada. Recurso improvido ${ }^{134}$.

(grifo nosso)

TRIBUNAL DE JUSTIÇA DO RIO DE JANEIRO

$19^{a}$ Câmara Cível

Apelação Cível n ${ }^{\circ}$ 2007.001.48529

Apelante: Village Dos Oitis Comercial Ltda.

Apelados: Fernando Fernandes e Outra

Relatora: JDS. Desembargadora Katia Torres

Apelação cível. Alienação. Fiduciária de bem imóvel. Pretensão de rescisão contratual deduzida pelo devedor fiduciante. Impossibilidade. Matéria regulada por lei específica, que prevalece diante da norma geral, em razão do critério da especialidade. Mora expressamente reconhecida pelos devedores, o que, por si só, implica em consolidação da propriedade em nome do fiduciário. Recurso provido $^{135}$.

(grifo nosso)

Em relação ao lugar, deverá a notificação ser feita, em regra, no domicílio do devedor ou no imóvel objeto da propriedade fiduciária. Frederico Henrique Viegas de Lima afirma que, para evitar que a intimação

oficial do competente Registro de Imóveis promover a intimação por edital, publicado por três dias, pelo menos, em um dos jornais de maior circulação local ou noutro de comarca de fácil acesso, se no local não houver imprensa diária.

${ }^{134}$ TJRJ, Agravo de Instrumento $\mathrm{n}^{\circ}$ 2006.002.18991, Rel. Desembargador José Carlos Varanda, Rio de Janeiro, 30 de maio de 2007.

${ }^{135}$ TJRJ, Apelação Cível n ${ }^{\circ}$ 2007.001.48529, Rel. Desembargadora Kátia Torres, Rio de Janeiro, 16 de outubro de 2007. 
seja frustrada, "o credor fiduciário deve, sempre que não possa precisar o melhor local para a efetivação da mesma, realizá-la em ambos"136.

Quanto ao conteúdo da intimação, o mesmo deverá prever prazo de quinze dias para que o devedor pague o valor indicado no demonstrativo de débito que englobará os seguintes itens, conforme previsão do artigo 26 $\S 1^{\circ}$ da Lei $n^{\circ} 9.514$ de $1997^{137}$ : a prestação vencida e as que se vencerem até a data do pagamento, os juros convencionais, as penalidades e os demais encargos contratuais, os encargos legais, inclusive tributos, as contribuições condominiais imputáveis ao imóvel, além das despesas de cobrança e de intimação.

Esclarece Mario Pazutti Mezzari que é muito importante que a carta de intimação não deixe margem para dúvidas quanto ao valor reclamado, pois o Registro de Imóveis não dispõe de contadoria para fazer cálculos em nome e para o credor. Muito menos se responsabilizará por eles ${ }^{138}$. Ademais, em caso de impugnação dos cálculos apresentados na intimação, o devedor não deverá fazê-lo perante o Registro de Imóveis, mas sim através de medida judicial, seja para sustar a mora ou para consignar o valor que entende devido pedindo, cumulativamente, a interrupção do processo intimatório registral. Complementa ainda o referido jurista que

sua apenas inconformidade com o valor reclamado não sustará a intimação e a constituição em mora, semelhantemente ao que ocorre com o protesto cambial de título de crédito, onde as alegações do devedor são lançadas no instrumento do protesto, mas este é lavrado apesar delas ${ }^{139}$.

Em suma, o devedor possui apenas como defesa da constituição em mora a comprovação de a mesma ser inexistente. Caso contrário, deverá

\footnotetext{
${ }^{136}$ LIMA, Frederico Henrique Viegas de. Da alienação fiduciária em garantia de coisa imóvel, p. 130.

137 Art. $26 \S 1^{\circ}$ Para os fins do disposto neste artigo, o fiduciante, ou seu representante legal ou procurador regularmente constituído, será intimado, a requerimento do fiduciário, pelo oficial do competente Registro de Imóveis, a satisfazer, no prazo de quinze dias, a prestação vencida e as que se vencerem até a data do pagamento, os juros convencionais, as penalidades e os demais encargos contratuais, os encargos legais, inclusive tributos, as contribuições condominiais imputáveis ao imóvel, além das despesas de cobrança e de intimação.

${ }^{138}$ MEZZARI, Mario Pazutti. Alienação Fiduciária da Lei n. 9.514, de 20-11-1997, p. 62.

${ }^{139}$ MEZZARI, Mario Pazutti. Alienação Fiduciária da Lei n. 9.514, de 20-11-1997, pp. 62 e 63.
} 
submeter-se ao pagamento dos valores devidos ou questioná-los judicialmente.

Preenchidas as formalidades definidas pelo artigo 26 da Lei $\mathrm{n}^{\circ} 9.514$ de 1997, será a intimação tida como instrumento bastante para constituir o fiduciante em mora. Conforme dito anteriormente, ao devedor, ser-lhe-á concedido o prazo de quinze dias, contados a partir do recebimento da intimação, para efetuar o pagamento da importância devida. Aproveitando o fiduciante esta oportunidade, purgará a mora e o contrato de alienação fiduciária em garantia será convalidado (26 §5º da Lei $n^{\circ} 9.514$ de $\left.1997^{140}\right)$. Para que o devedor purgue a mora, deverá comparecer ao Registro de Imóveis e pagar o que é devido mediante depósito da importância, que será remetida pelo Oficial do Registro de Imóveis ao fiduciário dentro de três dias, sendo descontadas as despesas de cobrança e intimação ${ }^{141}$.

Todavia, caso o devedor não purgue a mora, segundo o artigo $26 \S 7^{\circ}$ da Lei $\mathrm{n}^{\mathrm{o}} 9.514$ de $1997^{142}$, deverá o Oficial do Registro de Imóveis certificar este evento ao fiduciário, bem como promover a averbação da consolidação da propriedade em seu nome face à comprovação de pagamento do imposto de transmissão inter vivos ${ }^{143}$ e, caso o imóvel seja bem enfitêutico, o pagamento do laudêmio..

É mister observar, que a propriedade consolidada em nome do fiduciário não é plena, havendo a obrigação de aliená-la, seja judicialmente ou através do procedimento criado pela própria Lei $n^{0} 9.514$ de 1997 , para satisfação de seu crédito. Nesse sentido, ensina Ebert Chamoun que

\footnotetext{
${ }^{140}$ Art. $26 \$ 5^{\circ}$ Purgada a mora no Registro de Imóveis, convalescerá o contrato de alienação fiduciária.

${ }^{141}$ Art. $26 \$ 6^{\circ} \mathrm{O}$ oficial do Registro de Imóveis, nos três dias seguintes à purgação da mora, entregará ao fiduciário as importâncias recebidas, deduzidas as despesas de cobrança e de intimação.

142 Art. $26 \S 7^{\circ}$ Decorrido o prazo de que trata o $\S 1^{\circ}$ sem a purgação da mora, o oficial do competente Registro de Imóveis, certificando esse fato, promoverá a averbação, na matrícula do imóvel, da consolidação da propriedade em nome do fiduciário, à vista da prova do pagamento por este, do imposto de transmissão inter vivos e, se for o caso, do laudêmio.

${ }^{143}$ Sobre o pagamento do imposto de transmissão inter vivos, Renan Miguel Saad observa que deverá ser pago pelo fiduciário e não repassado ao fiduciante, pois é daquele a responsabilidade. (SAAD, Renan Miguel. A alienação fiduciária sobre bens imóveis, p. 239.).
} 
O proprietário, e agora possuidor, é obrigado de imediato, vender a coisa. Não pode continuar sendo proprietário, em razão da proibição trazida pela alienação fiduciária, inclusive pelo projeto, de pacto comissório, que permitiria ao credor, tornando-se dono automaticamente, com o não pagamento da obrigação. Isto não pode acontecer. Então ele tem que vender. $^{144}$

Além disso, decorre da consolidação da propriedade o direito de o fiduciário requerer ao Poder Judiciário, antes da venda do imóvel, a reintegração liminar na posse do mesmo, para que o fiduciante promova a desocupação em sessenta dias. Igual direito assiste ao adquirente do imóvel, pois, para que seja efetuada a venda em leilão, não é necessário que o imóvel esteja desocupado ${ }^{145}$.

De acordo com o artigo 30 da Lei $n^{\circ} 9.514$ de $1997^{146}$, a reintegração será concedida liminarmente para desocupação em sessenta dias, uma vez comprovada a regular consolidação da propriedade através da observância dos procedimentos de cobrança e de constituição do devedor em mora ${ }^{147}$.

Ressalta Melhim Namem Chalhub que por se tratar de medida que requer apreciação e decisão imediatas, é mister que os fatos sejam comprovados de maneira cristalina, podendo ser feitos por meio da apresentação do contrato de alienação fiduciária, da inexecução contratual e da consolidação da propriedade fiduciária, sendo estes últimos comprovados pela certidão do Registro de Imóveis ${ }^{148}$. Qualquer irregularidade ou dúvida acerca da constituição da mora ou da consolidação da propriedade em favor do fiduciário pode afastar a concessão da liminar

\footnotetext{
${ }^{144}$ CHAMOUN, Ebert. Depoimento na Comissão Especial do Projeto de Código Civil na Câmara dos Deputados em 06.08.1975, apud LIMA, Frederico Henrique Viegas de. Da alienação fiduciária em garantia de coisa imóvel, p. 134.

${ }_{145}$ A respeito, Mario Pazutti Mezzari arrisca dizer que nunca ocorrerá leilão com o imóvel desocupado, pois, em resumo, os leilões devem ser concluídos em quarenta e cinco dias; e a desocupação, se concedida a liminar, dar-se-á em sessenta dias. Portanto, é evidente a conclusão: o imóvel será leiloado sempre estando ocupado pelo devedor, salvo se (milagre!) este desocupá-lo espontaneamente. (MEZZARI, Mario Pazutti. Alienação Fiduciária da Lei n. 9.514, de 20-111997, p. 57.).

146 Art. 30. É assegurado ao fiduciário, seu cessionário ou sucessores, inclusive o adquirente do imóvel por força do público leilão de que tratam os $\S \S 1^{\circ}$ e $2^{\circ}$ do art. 27 , a reintegração na posse do imóvel, que será concedida liminarmente, para desocupação em sessenta dias, desde que comprovada, na forma do disposto no art. 26, a consolidação da propriedade em seu nome.

${ }^{147}$ Para situações envolvendo locação do imóvel, observar o disposto no artigo $27 \S 7^{\circ}$ da Lei $n^{\circ}$ 9.514 de 1997.

${ }^{148}$ CHALHUB, Melhim Namem. Negócio Fiduciário, p. 237.
} 
de reintegração de posse, bem como se o esbulho promovido pelo devedor tiver duração superior a um ano e dia.

Por fim, é oportuno dizer que, a partir da alteração promovida pela Lei $n^{\circ} .10 .931$ de 2004, a qual incluiu o artigo 37-A à Lei $n^{0} 9.514$ de $1997^{149}$, na hipótese de o fiduciante permanecer no imóvel por prazo superior aos sessentas dias, incidindo na prática de esbulho possessório, fará jus o fiduciário à taxa de ocupação do imóvel conforme os ditames do referido artigo. Igualmente, deverá o fiduciante arcar com as despesas tributárias, condominiais e outras que recaiam sobre o imóvel até a data em que o fiduciário seja imitido na posse conforme indicação do artigo 27 §8 da Lei $n^{0} 9.514$ de $1997^{150}$.

\subsubsection{Leilão}

Após a consolidação da propriedade, em cumprimento ao artigo 27 da Lei $\mathrm{n}^{0} 9.514$ de $1997^{151}$, deverá o fiduciário, em trinta dias contados da averbação mencionada, promover público leilão para a venda do bem. No entanto, com a inclusão do $\S 8^{\circ}$ ao artigo 26 da Lei $n^{\circ} 9.514^{152}$ de 1997 promovida pela Lei $\mathrm{n}^{\mathrm{o}} 10.931$ de 2004, caso o fiduciante dê seu direito eventual ao imóvel em pagamento da dívida, e o fiduciário anua, ficam dispensados os procedimentos de alienação do bem imóvel previstos no artigo 27 predito $^{153}$.

\footnotetext{
149 Art. 37-A. O fiduciante pagará ao fiduciário, ou a quem vier a sucedê-lo, a título de taxa de ocupação do imóvel, por mês ou fração, valor correspondente a um por cento do valor a que se refere o inciso VI do art. 24, computado e exigível desde a data da alienação em leilão até a data em que o fiduciário, ou seus sucessores vier a ser imitido na posse do imóvel.

150 Art. $27 \$ 8^{\circ}$ Responde o fiduciante pelo pagamento dos impostos, taxas, contribuições condominiais e quaisquer outros encargos que recaiam ou venham a recair sobre o imóvel, cuja posse tenha sido transferida para o fiduciário, nos termos deste artigo, até a data em que o fiduciário vier a ser imitido na posse.

${ }^{151}$ Art. 27. Uma vez consolidada a propriedade em seu nome, o fiduciário, no prazo de trinta dias, contados da data do registro de que trata o $\$ 7^{\circ}$ do artigo anterior, promoverá público leilão para a alienação do imóvel. (...).

${ }^{152}$ Art. $26 \S 8^{\circ} \mathrm{O}$ fiduciante pode, com a anuência do fiduciário, dar seu direito eventual ao imóvel em pagamento da dívida, dispensados os procedimentos previstos no art. 27.

${ }^{153}$ DANTZGER, Afrânio Carlos Camargo. Alienação Fiduciária de Bens Imóveis, p. 76.
} 
Não ocorrendo o preceituado no artigo $26 \S 8^{\circ}$ da Lei $n^{\circ} 9.514$ de 1997, o bem imóvel será levado a público leilão pelo valor estabelecido no artigo 24 inciso VI da referida Lei. Caso não seja alcançado o preço mínimo, o fiduciário deverá promover, nos quinze dias seguintes, um segundo leilão ${ }^{154}$.

Nesta hipótese o preço mínimo do imóvel será o valor da dívida, das despesas, dos prêmios de seguro, dos encargos legais, inclusive tributos, e das contribuições condominiais, conforme rezam os $\S \S 2^{\circ}$ e $3^{\circ}$ do Artigo 27 da Lei $n^{\circ} 9.514$ de $1997^{155}$. Esclarece Frederico Henrique Viegas de Lima que

a realização do segundo leilão é feita em bases diversas das do primeiro, uma vez que não é mais necessário o atingimento do valor acordado entre as partes quando da contratação da alienação fiduciária em garantia. Desaparecem a possibilidade e o conseqüente direito do devedor fiduciante de ver o bem ser leiloado pelo valor consignado no contrato. Toma-se por base o valor da dívida, juntamente com o das despesas. ${ }^{156}$

Ocorrendo a venda do imóvel, no segundo público leilão, por valor superior à dívida e às despesas, o credor deverá entregar, dentro dos cinco dias subseqüentes à venda, o saldo remanescente, o que importará em recíproca quitação. Vale atentar que o artigo $\$ 4^{\circ}$ da Lei $n^{\circ} 9.514$ de $1997^{157}$ afastou a aplicação do artigo 1.219 do Código Civil (o texto do referido $\S^{\circ}$ refere-se ao artigo 516 do Código Civil de 1916). Dessa forma, não caberá

${ }^{154}$ Art. $27 \S 1^{\circ}$ Se no primeiro público leilão, o maior lance oferecido for inferior ao valor do imóvel, estipulado na forma do incido VI do art. 24, será realizado o segundo leilão, nos quinze dias seguintes.

${ }^{155}$ Art. $27 \S 2^{\circ}$ No segundo leilão, será aceito o maior lance oferecido, desde que igual ou superior ao valor da dívida, das despesas, dos prêmios de seguro, dos encargos legais, inclusive tributos, e das contribuições condominiais.

$\$ 3^{\circ}$ Para os fins do disposto neste artigo, entende-se por:

I - dívida: o saldo devedor da operação de alienação fiduciária, na data do leilão, nele incluídos os juros convencionais, as penalidades e os demais encargos contratuais;

II - despesas: a soma das importâncias correspondentes aos encargos e custas de intimação e as necessárias à realização do público leilão, nestas compreendidas as relativas aos anúncios e à comissão do leiloeiro.

${ }^{156}$ LIMA, Frederico Henrique Viegas de. Da alienação fiduciária em garantia de coisa imóvel, p. 141.

$157 \$ 4^{\circ}$ Nos cinco dias que se seguirem à venda do imóvel no leilão, o credor entregará ao devedor a importância que sobejar, considerandos-e nela compreendido o valor da indenização de benfeitorias, depois de deduzidos os valores da dívida e das despesas e encargos de que tratam os $\S \S 2^{\circ}$ e $3^{\circ}$, fato esse que importará em recíproca quitação, não se aplicando o disposto na parte final do art. 516 do Código Civil. 
ao fiduciante o direito de indenização sobre as benfeitorias necessárias e úteis, tampouco o direito de retenção sobre as mesmas. Sobre o assunto, pronuncia-se Mario Pazutti Mezzari:

A retenção do imóvel por benfeitoria e/ou o pedido de indenização poderia truncar o livre andamento do processo de rescisão e de liquidação do contrato de alienação fiduciária. Especialmente na fase final, quando o legislador visou criar rapidez por meio de procedimentos novos. Consciente do risco que a retenção traria à pretendida celeridade na execução da garantia, a Lei n. 9.514/97 pretende ter criado novos mecanismos que afastem essa ameaça, ao estipular nos $\S \S^{\circ}$ e $5^{\circ}$ do art. 27, que a entrega ao devedor dos valores que sobejarem à dívida e demais encargos, após a realização do leilão, implicará a plena, justa e satisfatória indenização das benfeitorias, e a quitação por todos os valores que o devedor já tenha pago. E afastou expressamente a incidência da parte final do disposto no art. 516 (atual 1.219) do Código Civil, vale dizer, exatamente o que cria o direito de retenção ${ }^{158}$.

(nossa alteração)

Por outro lado, caso o valor pago pelo bem seja integralmente consumido pela satisfação do crédito do fiduciário, haverá quitação de fiduciário e fiduciante, sem que nenhuma quantia seja entregue a este. $\mathrm{O}$ fiduciário nada terá de devolver ou indenizar a título de benfeitorias e de valores pagos como entrada ou prestações ${ }^{159}$.

Se frustrado o segundo leilão, isto é, se o maior lance oferecido não for igual ou superior ao valor da dívida e dos encargos, a dívida será considerada extinta, sendo fornecido ao fiduciante termo de quitação nos cinco dias posteriores ao segundo leilão, de acordo com o preceituado nos $\S \S 5^{\circ}$ e $6^{\circ}$ do artigo 27 da Lei $n^{\circ} 9.514$ de $1997^{160}$. Em contrapartida, o fiduciário passará a possuir a propriedade plena do imóvel, podendo dispor do mesmo da maneira que melhor lhe aprouver, ou ainda, podendo ficar com ele ${ }^{161}$. Observa Frederico Henrique Viegas de Lima que o título hábil

\footnotetext{
${ }_{158}^{158}$ MEZZARI, Mario Pazutti. Alienação Fiduciária da Lei n. 9.514, de 20-11-1997, p. 80. ${ }^{159}$ MEZZARI, Mario Pazutti. Alienação Fiduciária da Lei n. 9.514, de 20-11-1997, p. 81.

${ }^{160}$ Art. $27 \S 5^{\circ} \mathrm{Se}$, no segundo leilão, o maior lance oferecido não for igual ou superior ao valor referido no $\$ 2^{\circ}$, considerar-se-á extinta a dívida e exonerado o credor da obrigação de que trata o $\S 4^{\circ}$.

Art $27 \S 6^{\circ} \mathrm{Na}$ hipótese de que trata o parágrafo anterior, o credor, no prazo de cinco dias a contar da data do segundo leilão, dará ao devedor quitação da dívida, mediante termo próprio.

${ }^{161}$ Cristiano Chaves de Farias e Nelson Rosenvald consideram ser inconstitucional o dispositivo que permite que o segundo leilão se aceite o maior lance oferecido, sendo bastante que supere o valor do débito em aberto. Apontam que, se não houver lance que atinja o mínimo, a pessoa
} 
para que o credor leve a registro sua propriedade plena é a carta de adjudicação judicial ou passada pelo leiloeiro público, que deverá conter a circunstância de haverem sido realizados dois leilões com resultados negativos $^{162}$.

Como bem aponta Renan Miguel Saad, o legislador, ao editar a Lei $n^{0} 9.514$ de 1997, diferentemente do Decreto-Lei 911 sobre a alienação fiduciária de móveis, nega ao fiduciário o direito de prosseguir com a execução de um eventual resíduo existente ${ }^{163}$. Assim, previu o legislador situação mais benéfica ao fiduciário do que na alienação fiduciária de bens móveis.

Por fim, não se poderia encerrar o presente capítulo sem lembrar que a formação e a interpretação contratuais, inclusive na alienação fiduciária em garantia, necessitam obedecer aos princípios da boa-fé objetiva e da função social do contrato. Por este prisma, deve-se entender que o procedimento do artigo 27 da Lei nº 9.514 de 1997 para satisfação do crédito seja repelido nas ocasiões em que o fiduciante tenha adimplido substancialmente $^{164}$ as obrigações contratuais. Subsistirá a relação contratual, devendo o credor cobrar o crédito formas previstas na legislação processual civil. Já se manifestou o Tribunal de Justiça do Rio de Janeiro sobre o assunto no que tange à alienação fiduciária de bens móveis:

\author{
TRIBUNAL DE JUSTIÇA DO RIO DE JANEIRO \\ $2^{\text {a }}$ Câmara Cível \\ Agravo de Instrumento $n^{\circ}$ 2007.002.35681 \\ Agravante: Banco Citbank S.A.
}

\footnotetext{
perderá o imóvel e tudo o que pagou. Tal fato ofenderia o devido processo legal, porque a pessoa será privada do direito de propriedade sem a garantia constitucional do processo e da presença do Estado-juiz. (FARIAS \& ROSENVALD. Direitos Reais, p. 387.).

${ }^{162}$ LIMA, Frederico Henrique Viegas de. Da alienação fiduciária em garantia de coisa imóvel, p. 142.

${ }^{163}$ SAAD, Renan Miguel. A alienação fiduciária sobre bens imóveis, p. 254.

${ }^{164} \mathrm{O}$ adimplemento substancial consiste em um resultado tão próximo do almejado, que não chega a abalar a reciprocidade, o sinalagma das prestações correspectivas. Por isso, pelo princípio da continuidade das relações contratuais, mantém-se o contrato, concedendo-se ao credor direito a ser ressarcido pelos defeitos da prestação, porque o prejuízo, ainda que secundário, se existe deve ser reparado. Entende a doutrina que a resolução do contrato revelaria um exercício abusivo de um direito. (OMAIRI, Elissane Leila. A doutrina do adimplemento substancial e sua recepção pelo Direito brasileiro. Disponível em http://www.direitonet.com.br/artigos/x/20/64/2064/. em 29 de maio de 2008. )
} 
Agravada: Ângela de Souza

Relatora: Desembargadora Elisabete Filizzola

Agravo de Instrumento. Alienação Fiduciária. Ação de busca e apreensão. Purga da mora.

Recurso interposto contra decisão que revogou a liminar deferida, determinando a devolução do veículo apreendido. A interpretação do artigo $3^{\text {o }}$ do Dec. Lei ${ }^{\circ} 911 / 69$, seja na redação original ou na que lhe deu a Lei $\mathrm{n}^{\mathrm{o}} 10.931 / 2004$, é a de que a purga da mora pode ser feita pelo valor do débito vencido e não pela integralidade do ajustado.

Além do adimplemento substancial do contrato, a agravada cumpriu o disposto no $\$ 2^{\circ}$, do art. $3^{\circ}$ do Decreto-Lei $911 / 69$, ao efetuar o pagamento das parcelas vencidas a fls. 59, conforme planilha de débito apresentado pelo credor a fls. 18 , dentro do prazo de 5 dias após executada a liminar. RECURSO DESPROVIDO ${ }^{165}$.

(grifo nosso)

${ }^{165}$ TJRJ, Agravo de Instrumento n. 2007.002.35681, Rel. Desembargadora Ângela de Souza, Rio de Janeiro, 30 de janeiro de 2008. 


\section{Aspectos interessantes sobre a consolidação da propriedade plena}

\subsection{Pacto comissório}

Poder-se-ia pensar que a incorporação do bem ao patrimônio do credor depois de frustrados os dois leilões fere a vedação do pacto comissório. No entanto, conforme lembra Melhim Namem Chalhub, a propriedade fiduciária que o credor possui, ao celebrar o contrato de alienação fiduciária em garantia, é temporária, ou seja, durará até o implemento da condição resolutiva que é o pagamento da dívida. Assim, adimplida a mesma, o credor perde a propriedade. Por outro lado, caso a condição não ocorra, o credor consolida a propriedade em seu nome. Nas palavras do jurista, "uma eventual proibição a que o proprietário fiduciário fique com o imóvel, se a dívida não for paga, implicaria a própria negação da teoria da propriedade resolúvel, desnaturando-a inteiramente"166. Completa o renomado jurista que a Lei $n^{0} 9.514 / 97$ optou por atribuir ao credor a propriedade resolúvel, ainda que com limitações, caso o fiduciante deixe de pagar a dívida e desde que cumpridas as formalidades legais.

Ademais, outro argumento interessante é o trazido por Pontes de Miranda, citado por Melhim Namem Chalhub, uma vez que demonstra que a permissão da consolidação da propriedade plena na pessoa do fiduciário reside na questão de se tratar de direito real sobre bem próprio e não de direito real sobre coisa alheia, como é o caso da hipoteca:

Quem é outorgado em pacto de transmissão em segurança não poderia

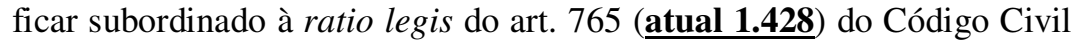
porque já é adquirente; não se poderia negar tornar-se aquilo que já é; pode-se vedar o vir a ser. Aplicar-se o art. 765 (atual 1.428) ao outorgado em pacto de transmissão em segurança seria negar-se a alguém poder continuar a ser o que já é. ${ }^{167}$

(nossa alteração)

\footnotetext{
${ }^{166}$ CHALHUB, Melhim Namem. Negócio Fiduciário, p. 221.

${ }^{167}$ MIRANDA, Pontes de. Tratado de Direito Privado, tomo XXI, p. 333, apud SAAD, Renan Miguel. A alienação fiduciária sobre bens imóveis, p. 254.
} 
Além disso, apesar da inegável segurança e da redução de riscos que o fiduciário possui na alienação fiduciária em garantia imobiliária, é imprescindível destacar que a incorporação do imóvel ao seu patrimônio não traduz locupletamento. Tal afirmativa encontra respaldo no fato de o fiduciário ter emprestado dinheiro ao fiduciante e estar recebendo um imóvel, cuja apreciação de mercado não lhe considera valioso, consistindo, portanto, em bem de liquidez duvidosa. Se não apareceu interessado em comprar o imóvel por quantia equivalente à dívida, frise-se por valor inferior ao bem, resta ao credor arcar com as despesas fiscais, condominiais e de manutenção até que consiga vender a coisa e, somente, então, recuperar a liquidez do crédito.

Acerca da ausência de enriquecimento sem causa, relembra Afrânio Carlos Camargo Dantzger que na execução judicial o bem é levado à primeira praça pelo valor da avaliação e à segunda por qualquer valor desde que não seja considerado vil. Assim, se o juiz aceitar o lance ofertado, que, inclusive, poderá ser feito pelo próprio credor, o fato não configurará enriquecimento sem causa ${ }^{168}$.

\subsection{Perda das parcelas pagas e 0 artigo 53 do Código de Defesa do Consumidor}

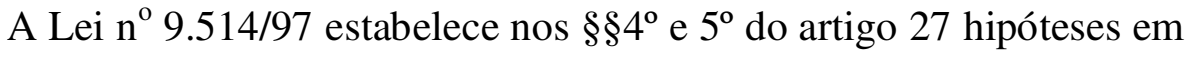
que a dívida será considerada extinta sem que o fiduciante tenha direito a receber valor algum sobre a venda do imóvel objeto da garantia. Assim, pode causar angústia e surpresa que o legislador tenha inserido tal regra no ordenamento jurídico pátrio, ao passo que o Código de Defesa do consumidor garante em seu artigo 53, abaixo transcrito, a nulidade das cláusulas que dispõem sobre a perda da totalidade das prestações em razão do inadimplemento contratual:

${ }^{168}$ DANTZGER, Afrânio Carlos Camargo. Alienação Fiduciária de Bens Imóveis, p. 78. 
Art. 53. Nos contratos de compra e venda de móveis ou imóveis mediante pagamento em prestações, bem como nas alienações fiduciárias em garantia, consideram-se nulas de pleno direito as cláusulas que estabeleçam a perda total das prestações pagas em benefício do credor que, em razão do inadimplemento, pleitear a resolução do contrato e a retomada do produto alienado.

Assim, vislumbramos, de um lado, o Código de Defesa do Consumidor e, de outro, a Lei $\mathrm{n}^{\mathrm{0}} 9.514$ de 1997, promulgada sete anos após o código consumeirista.

Para dirimir a polêmica apresentada, é necessário analisar alguns aspectos pertinentes, e, por fim, a jurisprudência pátria.

Primeiramente, prevê a Lei de Introdução ao Código Civil em seu artigo $2^{\circ}$ que lei de vigência não temporária vigorará até que outra a modifique ou revogue. Diz ainda o $\$ 2^{\circ}$ do mesmo artigo que "lei nova, que estabeleça disposições gerais ou especiais a par das já existentes, não revoga nem modifica a lei anterior". A partir daí, conclui-se que, sendo a Lei $\mathrm{n}^{\circ} 9.514$ de 1997 posterior ao Código de Defesa do Consumidor e regulando de forma específica a alienação fiduciária em garantia de bens imóveis, prevalece no que ambas divergirem. Neste sentido, apresenta-se o entendimento de Melhim Namem Chalhub, citado por Afrânio Carlos Camargo Dantzger:

Com efeito, a alienação fiduciária de bens imóveis (assim como a de bens móveis) tem disciplina própria, que regula de maneira específica e exaustiva as consequiências da mora e a excussão do bem objeto da garantia, tudo com vistas à observância dos mesmos princípios de equidade e de equilíbrio das relações contratuais também perseguidos pelo Código de Defesa do Consumidor e, assim sendo, hão de prevalecer as leis especiais, em caso de conflitos de normas.

No caso da alienação fiduciária de bens imóveis, a prevalência se dá não só em razão do critério da especialidade da lei, como, também, pelo critério da cronologia, pois a lei que disciplina a alienação fiduciária de bens imóveis é posterior ao Código de Defesa do Consumidor ${ }^{169}$.

Ademais, além do conflito de normas, há doutrina no sentido de que a Lei n ${ }^{\circ} 9.514$ de 1997 está ajustada com os ditames do Código de Defesa

169 CHALHUB, Melhim Namem. Alienação Fiduciária e direito do consumidor, apud DANTZGER, Afrânio Carlos Camargo. Alienação Fiduciária de Bens Imóveis, p. 85. 
do Consumidor, pois: ordena que o fiduciário devolva ao fiduciante a diferença por ventura existente entre o valor da sua dívida e o valor alcançado pela venda do imóvel no público leilão, afastando a possibilidade de o devedor perder a totalidade das parcelas; e se, no entanto, no segundo público leilão, o maior valor oferecido for equivalente à dívida e às despesas ou ainda se for frustrado, prescreve a Lei $n^{0} 9.514$ de 1997, que a dívida será considerada extinta, sendo vedado ao fiduciário a cobrança de saldo devedor.

Neste último ponto, esclarece Afrânio Carlos Camargo Dantzger que, não há a perda das parcelas pagas, pois resta configurado um sistema de compensação: se por um lado o fiduciante inadimplente acaba ficando sem o imóvel dado em garantia de sua dívida, por outro, desta será exonerado. $^{170171}$.

Adicionalmente, de acordo com o jurista Arnoldo Wald, não se cogita a perda das prestações pagas nas situações descritas, pois, o valor mínimo do segundo leilão corresponde ao valor original da dívida, somados os juros, correção monetária, encargos e multas e subtraídas as prestações já pagas. Assim, na sistemática da Lei n ${ }^{\circ} 9.514$ de 1997, as prestações pagas já foram consideradas na fixação do saldo devedor ${ }^{172}$.

Outro aspecto a ser apreciado é o trazido pelos juristas José Manoel de Arruda Alvim Netto e Afrânio Carlos Camargo Dantzger, que defendem a não aplicação do artigo 53 do Código de Defesa do Consumidor à alienação fiduciária por ser contrário à própria natureza do contrato. Afirma José Manoel de Arruda Alvim Netto que

\footnotetext{
${ }^{170}$ DANTZGER, Afrânio Carlos Camargo. Alienação Fiduciária de Bens Imóveis, p. 86.

${ }^{171}$ Sob a mesma ótica, Renan Miguel Saad ensina que (...) parece que o raciocínio do legislador seguiu a seguinte lógica: o fiduciário seria prejudicado por ter que converter um crédito com acentuada liquidez (em dinheiro) por outro que, por ser imobilizado, muitas vezes, não tem tanta liquidez; já o fiduciante, em compensação, embora perdesse um direito real à aquisição, seria beneficiado pela extinção de uma dívida teoricamente superior ao valor do imóvel. (SAAD, Renan Miguel. A alienação fiduciária sobre bens imóveis, p. 261.).

172 WALD, Arnoldo. Do regime legal da alienação fiduciária de imóveis e sua aplicabilidade em operações de financiamento de bancos de desenvolvimento, apud DANTZGER, Afrânio Carlos Camargo. Alienação Fiduciária de Bens Imóveis, p. 91.
} 
No contrato de compra e venda a prestações, o devedor recebe uma coisa, pela qual vai pagando; havendo rescisão haverá de devolver a coisa, e é por isso que deve receber de volta o que por ela pagou; no sistema da Lei 9.514/1997 o numerário destina-se à aquisição da coisa, é originariamente do credor e por isso deve devolvê-lo, pois que foi recebido com a obrigação de devolução; se o credor, a seu turno, houvesse de devolver "esse numerário", que recebera em pagamento, estaria sempre perdendo, e estaria "sempre perdendo" porque o produto da alienação fiduciária do bem imóvel destina-se ao pagamento do "resto do débito", ou seja, destina-se à reposição do patrimônio do credor, nada mais ${ }^{173}$.

No mesmo sentido, Afrânio Carlos Camargo Dantzger distingue o compromisso de compra e venda de imóvel a prestações e a alienação fiduciária de imóveis nos seguintes parâmetros: naquela as parcelas pagas ao credor são provenientes do patrimônio do próprio devedor, por isso, prevê o artigo 53 supracitado a devolução no caso de inadimplemento, com a perda do sinal para composição das perdas e danos, lucrando o vendedor com a própria venda do imóvel ${ }^{174}$. Diferentemente, na alienação fiduciária, sendo o negócio principal o empréstimo, o fiduciário não lucrará com a venda, mas sim com os encargos e as taxas contratuais da mesma forma que ocorre no empréstimo comum. Caracterizam as parcelas pagas mera amortização do que emprestou o fiduciário ao fiduciante. Portanto, alega que se estas parcelas forem devolvidas ao fiduciante, ser-lhe-ia assegurado o direito de utilizar o bem, sem nada pagar ${ }^{175}$.

Aponta o mesmo jurista que não se diferencia, no que diz respeito à dívida, a alienação fiduciária de bens imóveis, embora com garantia real, dos contratos de empréstimos bancários comuns. Destarte, em ambos, o credor lucrará com as taxas e encargos contratuais. Entretanto, na alienação fiduciária de bens imóveis, o devedor possui grande vantagem na hipótese de os dois públicos leilões serem frustrados, porque terá a dívida extinta. Já

\footnotetext{
${ }^{173}$ ALVIM NETTO, José Manoel de Arruda. Alienação Fiduciária e direito do consumidor, p. 45. apud DANTZGER, Afrânio Carlos Camargo. Alienação Fiduciária de Bens Imóveis, p. 87.

${ }^{174}$ DANTZGER, Afrânio Carlos Camargo. Alienação Fiduciária de Bens Imóveis, p. 88.

${ }^{175}$ É válido dizer que a parte final deste argumento pode ser afastada, caso entenda-se exigível do fiduciante o pagamento de taxa de ocupação semelhante ao que ocorre na situação prevista no artigo 37-A da Lei ${ }^{\circ} 9.514$ de 1997.
} 
nos empréstimos bancários comuns, apesar do inadimplemento do devedor, o credor tem o direito de executar a dívida toda ${ }^{176}$.

Em sentido oposto, afirmam Paulo Restiffe Neto e Paulo Sérgio Restiffe que há identidade entre as situações de compromisso comum de venda e compra de imóvel e a retomada de imóvel alienado fiduciariamente. Dessa forma, indicam que o silêncio da Lei $\mathrm{n}^{\circ} 9.514$ de 1997, quanto à devolução de importâncias no caso de leilão negativo, não pode ser interpretado contra o devedor. A omissão deverá ser compreendida considerando-se as normas dos artigos 51 e 53 do Código de Defesa do Consumidor e, conseqüentemente, assegurando-se ao fiduciante o decaimento parcial das parcelas, sendo vedada a perda total. São suas palavras:

Na alienação fiduciária sobre bens imóveis, o consumidor em mora é tratado com mais benevolência do que na alienação fiduciária sobre bens móveis, quanto à constituição em mora (...), ou no tocante à extinção da dívida em caso de insucesso da venda de excussão no segundo leilão (...). Daí que, no silêncio da Lei 9.514, em caso de não ocorrência da venda de excussão, o mutuário perca o imóvel, mas jamais a totalidade das prestações pagas, pelo que estará sujeito a um decaimento mínimo ${ }^{177}$.

Para corroborar sua tese, utilizam jurisprudência sobre compromisso de compra e venda de imóvel para pautar seu entendimento a respeito da alienação fiduciária de imóvel.

Respeitosamente, discorda-se da posição defendida pelos Restiffe. Pelo que vem sendo exposto, é patente a distinção entre os dois contratos em referência, sendo, portanto, duvidoso o aproveitamento de jurisprudência de um contrato para o outro no que diz respeito ao direito de o fiduciante receber parte do que pagou se a venda do imóvel em leilão for frustrada.

Por fim, apresenta-se a jurisprudência do Egrégio Tribunal de Justiça do Rio de Janeiro:

\footnotetext{
${ }^{176}$ DANTZGER, Afrânio Carlos Camargo. Alienação Fiduciária de Bens Imóveis, p. 89.

${ }^{177}$ RESTIFFE NETO, Paulo; RESTIFFE, Paulo Sérgio. Garantia Fiduciária. $3^{\mathrm{a}}$ ed. rev., atual. e ampl. - São Paulo: Editora Revista dos Tribunais, 2000. p. 257.
} 
TRIBUNAL DE JUSTIÇA DO RIO DE JANEIRO

$16^{\text {a }}$ Câmara Cível

Apelação Cível no 2007.001.38311

Apelante: Regina Kely de Souza Matos

Apelada: Village dos Oitis Comercial Ltda.

Relator: Desembargador Mario Robert Mannheimer

Ação de rescisão de escritura de Compra e Venda de Imóvel, com alienação fiduciária, face ao inadimplemento dos promitentes compradores que deixaram de efetuar o pagamento de parte do preço ajustado. Não aplicacão da jurisprudência do Colendo Superior Tribunal de Justica, no sentido de que nas ações de rescisão de compromisso de compra e venda, nas quais o promitente vendedor recupera o imóvel prometido à venda, deve-se proceder à devolução de parte do preço ao promitente comprador, por haver na hipótese, pacto de alienação fiduciária com base na Lei n. 9.514/1997, com a redação da Lei. 10.931/04. Não há violação aos conceitos emanados do Código de Defesa do Consumidor, em especial ao artigo 53 que veda a cláusula de decaimento, pelo procedimento de realização da garantia fiduciária previsto na Lei n. 9.514/1997. O citado diploma legal, em seu artigo 27, afasta a possibilidade de perda total das quantias pagas pelo devedor ao prever que o mutuante deverá reembolsarse do seu crédito, mediante a venda do bem em leilão, restituindo ao devedor o que sobejar. Não havendo o pagamento da dívida por um dos meios apontados em lei, tornar-se-á o fiduciário proprietário pleno do bem, procedendo-se ao termo de extinção e quitação da dívida, liberando-se o devedor fiduciante de eventual saldo devedor. Conhecimento e desprovimento do Apelo ${ }^{178}$.

(grifo nosso)

\section{TRIBUNAL DE JUSTIÇA DO RIO DE JANEIRO}

$11^{\text {a }}$ Câmara Cível

Apelação Cível nº 2007.001.06874

Apelantes: Antônio Paulo Akra Filho.e Outro

Apelada: Brascan Imobiliária Incorporações S/A

Relator: Desembargador Cláudio de Mello Tavares

Ação de reintegração de posse. Contrato de financiamento de imóvel com alienação fiduciária. Aplicação dos ditames da Lei no 9.514/97. Retenção por benfeitorias. Taxa de ocupação. Restituição de quantia em dinheiro aos fiduciantes.

Extrai-se dos autos, que os apelantes adquiriram um imóvel da apelada, estabelecendo a alienação fiduciária como garantia, mas, em virtude do inadimplemento das obrigações foram notificados para purgar a mora, e não exercendo tal faculdade, foi realizada a praça, cuja propriedade se consolidou em nome da apelada, por não haver licitantes. Destarte, esta intentou ação de reintegração de posse do imóvel, tendo o juízo deferido a liminar pleiteada na exordial, tornando-a definitiva através da sentença hostilizada.

Quanto às benfeitorias, verifica-se pela prova documental, que as mesmas se enquadram como voluptuárias, o que torna inaplicável a regra contida no artigo 1.219 do Código Civil/2002, prevalecendo, pois, os termos do

178 TJRJ, Apelação Cível n. 2007.001.38311, Rel. Desembargador Mario Robert Mannheimer, Rio de Janeiro, 11 de setembro de 2007. 
instrumento particular celebrado entre as partes, ratificado por escritura, que atende ao comando da Lei $n^{\circ} 9.514 / 97$, especificamente seu art. $27 \S 4^{\circ}$. A cláusula que estabelece o pagamento de taxa de ocupação pelos fiduciantes à fiduciária tem natureza de cláusula penal e finalidade de préfixação das perdas e danos, ou seja, durante o período em que restou configurado o esbulho possessório, não havendo que se considerar abusivo o percentual especificado no artigo 34-A da Lei $n^{\circ}$ 9.514/97.

Os artigos $26, \$ \$ 4^{\circ}, 5^{\circ}$ e $6^{\circ} ; 27$ e seus parágrafos, da Lei $n^{\circ} 9.514 / 97$ estabelecem que eventual direito de restituicão de quantia em dinheiro somente será possível na hipótese de o produto obtido com a venda em leilão público sobejar o saldo devedor, o que não é o caso dos autos, pois, sequer houve licitante. Recurso conhecido e improvido ${ }^{179}$.

(grifo nosso)

TRIBUNAL DE JUSTIÇA DO RIO DE JANEIRO

19 Câmara Cível

Origem: $3^{\text {a }}$ Vara Cível - Regional Barra da Tijuca

Apelação Cível n ${ }^{\circ}$ 2007.001.64492

Apelantes: Andréia Macedo Guedes e Marcus Vinícius de Souza Medeiros Apelados: Village dos Oitis Comercial Ltda. e Agora Sênior Corretora de Títulos e Valores Mobiliários S.A.

Relatora: Des. Denise Levy Tredler

C.R. 5

Apelação Cível. Pedido de rescisão contratual com restituição de $70 \%$ dos valores pagos. Contrato de compra e venda de imóvel com cláusula de alienação fiduciária. Inexistência de simulação ou de abusividade. Sentença que extingue o processo em relação ao primeiro réu e de improcedência em relação ao segundo, cuja manutenção se impõe. Desprovimento do recurso.

(...) São bastante evidentes as distinções que se traçam entre o contrato de compra e venda por alienação fiduciária e o contrato de compra e venda simples, regido pelo Código Civil. Quando as partes adotam a primeira espécie, o fazem para dar maior garantia ao credor, através do próprio bem adquirido e possibilitar ao devedor adquirente acesso ao crédito.

(...) Por conseqüência, não se pode admitir a devolução das parcelas pagas nos termos pretendidos, mas apenas o repasse dos valores que ultrapassarem o crédito do fiduciante, após a realização do leilão do bem, nos termos do art. 27 da Lei n. 9.514 de 1997 e seus parágrafos ${ }^{180}$.

Pelo exposto, percebe-se, que a jurisprudência corrobora o entendimento doutrinário sobre a não violação do artigo 53 da lei consumeirista nas situações em que há frustração da venda em leilão do bem, cabendo a propriedade plena do bem ao fiduciário e a extinção da dívida ao fiduciante.

${ }^{179}$ TJRJ, Apelação Cível n. 2007.001.06874, Rel. Desembargador Cláudio de Mello Tavares, Rio de Janeiro, 28 de março de 2007.

${ }_{180}$ TJRJ, Apelação Cível n ${ }^{\circ}$ 2007.001.64492, Rel. Desembargadora Denise Levy Tredler, Rio de Janeiro, 28 de janeiro de 2008. 


\section{Conclusão}

Neste trabalho monográfico, procurou-se demonstrar a importância da criação da alienação fiduciária de bens imóveis, estabelecida pela Lei ${ }^{\circ}$ 9.514 de 1997, pois, ao reduzir os riscos do negócio para o credor, facilitou o acesso ao crédito imobiliário ao devedor.

A alienação fiduciária imobiliária configura-se pela transferência fiduciária da propriedade do bem imóvel do devedor para o credor. Assim, distingue-se das demais garantias reais, pois nestas - penhor, anticrese e hipoteca - o titular da garantia tem um direito real na coisa alheia, enquanto na propriedade fiduciária o titular da garantia é titular de direito de propriedade, embora limitado pelo caráter fiduciário.

No que tange à caracterização da propriedade fiduciária imobiliária, demonstrou-se que diverge da propriedade fiduciária do Código Civil, uma vez que naquela o início e o término de sua duração são definidos por lei, e não pela vontade das partes.

Para a celebração do contrato de alienação fiduciária em garantia de bens imóveis, destacou-se que a Lei n ${ }^{\circ} 9.514$ de 1997 facilitou a utilização deste contrato, tendo em vista que: permite que qualquer pessoa figure como fiduciária, sendo afastada a discussão presente na contratação de alienação fiduciária de bens móveis; ampliou, ao longo dos dez anos de vigência da Lei, o objeto da alienação fiduciária; e estendeu a qualquer pessoa a possibilidade de celebração do contrato por instrumento particular com efeitos de instrumento público.

Acerca da extinção do contrato, observou-se que a adimplência do devedor obriga o credor a fornecer termo de quitação no prazo de trinta dias. Este documento, apresentado face ao Registro Geral de Imóveis, será suficiente para o cancelamento do registro da propriedade fiduciária. Por outro lado, o contrato também poderá ser extinto por inadimplência do devedor. Neste caso, apontou-se que, após expirado o prazo de carência, o credor poderá promover através do Registro Geral de Imóveis a intimação 
pessoal do devedor (podendo ser postal ou por edital conforme abordado), concedendo prazo para que o valor devido seja pago.

Se após a intimação o devedor permanecer inadimplente, a propriedade fiduciária consolida-se em favor do devedor. Neste ponto, alertou-se que o credor não terá a propriedade plena do bem, visto que deverá promover sua venda para satisfazer seu crédito, em respeito à vedação do pacto comissório. Todavia, o fiduciário tem o direito de requerer ao Judiciário a reintegração liminar da posse, provando a regular intimação da mora e a consolidação da propriedade. Concedida a liminar, terá o fiduciante o prazo de sessenta para desocupar o imóvel.

Inovou a Lei $\mathrm{n}^{0} 9.514$ de 1997 com o procedimento de excussão da garantia, o qual poderá ser realizado sem a intervenção do Poder Judiciário, evitando a procrastinação percebida, a exemplo, na excussão hipotecária. Outra inovação é a fuga da discussão da figura do depositário infiel e da prisão civil, pois inexiste o depósito na alienação fiduciária imobiliária.

Em relação ao procedimento de excussão supracitado, serão realizados dois públicos leilões. No primeiro, o preço mínimo para venda é o estabelecido pelas partes no contrato de alienação fiduciária e, no segundo leilão, caso o primeiro seja frustrado, o da dívida mais os encargos previstos na referida Lei. Vendido o bem, receberá o credor o valor da dívida e o devedor a quitação e eventual saldo que sobeje o valor mínimo da venda. Ao adquirente do imóvel assistirá o direito de requerer ao Judiciário a reintegração liminar da posse do bem, caso o fiduciante se recuse a desocupar o imóvel.

No entanto, se frustrada a venda no segundo leilão, observou-se que o devedor receberá a quitação da dívida, sendo vedada qualquer cobrança por eventual débito, e que, em contrapartida, o credor receberá a propriedade plena do bem. Nesse sentido, indicou-se posição mais favorável do devedor na alienação fiduciária imobiliária do que na alienação fiduciária de bens móveis, uma vez que nesta é permitida a cobrança do devedor em relação a resíduo de dívida. 
Oportunamente, acrescentou-se que por força da função social do contrato e da boa-fé objetiva, apesar de não haver previsão na Lei $\mathrm{n}^{\circ} 9.514$ de 1997, entende-se que o procedimento de excussão deve ser afastado pela utilização da Teoria do Adimplemento Substancial, caso o inadimplemento recaia sobre parcela ínfima da obrigação, cabendo ao credor a cobrança prevista na legislação processual civil.

Sobre as angústias dos fiduciantes, esclareceu-se a consolidação da propriedade plena em favor do fiduciário, assim como, a aplicabilidade do artigo 53 do Código de Defesa do Consumidor à alienação fiduciária imobiliária. A propósito, foram defendidas as posições, corroboradas por doutrina e jurisprudência, da inexistência de pacto comissório quando da frustração da venda nos leilões; e da não aplicação do artigo 53 da lei consumeirista pelos seguintes motivos: disciplina específica e posterior dada pela Lei n ${ }^{\circ} 9.514$ de 1997, ocorrência de sistema de compensação, consideração das parcelas pagas para cálculo do saldo devedor, existência de natureza peculiar da alienação fiduciária imobiliária, concessão de vantagem ao fiduciante pela quitação da dívida.

Por todo o exposto neste trabalho monográfico, infere-se que o contrato de alienação fiduciária em garantia de bens imóveis é instituto típico, criado por Lei e possui as características necessárias para continuar com sua crescente utilização. Se, por um lado, atende a população desejosa de adquirir imóvel próprio, por outro, acalma os credores ávidos por garantias que reduzam o risco contratual e que facilitam a recuperação do crédito.

Relembra-se que os contratos como materialização das promessas das partes e, por conseguinte, como forma de redução de risco, devem ser cumpridos e que o prêmio à inadimplência prejudica toda a sociedade, pois é pela segurança dada pelo cumprimento, que se oportuniza a maior celebração de contratos. No contrato de alienação fiduciária imobiliária não é diferente. Assim, finaliza-se com as palavras de Charles Guide, parte da epígrafe desta monografia: "o crédito é, pois, o modo de produção mais 
perigoso que vimos até agora, e só presta serviços nas sociedades cuja educação econômica está muito adiantada" ${ }^{\text {"181. }}$.

${ }^{181}$ GUIDE, Charles. Compêndio de Economia. 


\section{Referências Bibliográficas}

ALVES, José Carlos Moreira. Direito Romano. $13^{\mathrm{a}}$ ed. Rio de Janeiro: Forense, 2003.

BULGARELli, Waldirio. Títulos de Crédito. $16^{\mathrm{a}}$ ed. São Paulo: Atlas, 2000 .

CHALHUB, Melhim Namem. Negócio Fiduciário. Rio de Janeiro: Renovar, 1998.

DANTZGER, Afrânio Carlos Camargo. Alienação Fiduciária de Bens Imóveis. 2a ed. São Paulo: Método, 2007.

FARIAS, Cristiano Chaves; ROSENVALD, Nelson. Direitos Reais. $3^{\mathrm{a}}$ ed. Rio de Janeiro: Lumen Júris, 2006.

GOMES, Orlando. Alienação Fiduciária em Garantia. $3^{\mathrm{a}}$ ed. São Paulo: Editora Revista dos Tribunais, 1972.

GONÇALVES, Carlos Roberto. Direito Civil Brasileiro - volume V. $1^{\mathrm{a}}$ ed. São Paulo: Saraiva, 2006.

LIMA, Frederico Henrique Viegas de. Da alienação fiduciária em garantia de coisa imóvel. $2^{\mathrm{a}}$ ed. Curitiba: Juruá Editora, 2006.

MEZZARI, Mario Pazutti. Alienação Fiduciária da Lei n. 9.514, de 20-111997. $1^{a}$ ed. São Paulo: Saraiva, 1998.

OMAIRI, Elissane Leila. A doutrina do adimplemento substancial e sua recepção pelo Direito brasileiro. Disponível em http://www.direitonet.com.br/artigos/x/20/64/2064/. em 29 de maio de 2008. 
PAULA, Nice de. Estabilidade e mudança nas regras trouxeram mais $\begin{array}{llll}\text { recursos ao } & \text { setor. Disponível em }\end{array}$ http://oglobo.globo.com/economia/mat/2005/08/24/169575275.asp. Acesso em 20 de novembro de 2007.

PEREIRA. Caio Mario da Silva. Instituições de direito civil - volume IV. $18^{\mathrm{a}}$ ed. Rio de Janeiro: Forense, 2004.

PINHEIRO, Armando Castelar; SADDI, Jairo. Direito, Economia $e$ Mercados. Rio de Janeiro: Elsevier, 2005.

RESTIFFE NETO, Paulo; RESTIFFE, Paulo Sérgio. Garantia Fiduciária. $3^{\text {a }}$ ed. rev., atual. e ampl. - São Paulo: Editora Revista dos Tribunais, 2000.

ROSA JUNIOR, Luiz Emygdio Franco da. Títulos de Crédito. $4^{\mathrm{a}}$ ed. Rio de Janeiro: Renovar, 2006.

SAAD, Renan Miguel. A alienação fiduciária sobre bens imóveis. Rio de Janeiro: Renovar, 2001.

SIQUEIRA, Juliana. Expansão de crédito em 2007 supera estimativas do Itaú. Disponível em http://oglobo.globo.com/economia/mat/2007/11/06/327051496.asp . Acesso em 20 de novembro de 2007.

TJRJ, Agravo de Instrumento n. 2007.002.03812, Rel. Desembargador Ruyz Athaide Alcântara de Carvalho, Rio de Janeiro, 14 de agosto de 2007.

TJRJ, Agravo de Instrumento ${ }^{\circ}$ 2006.002.18991, Rel. Desembargador José Carlos Varanda, Rio de Janeiro, 30 de maio de 2007.

TJRJ, Apelação Cível n. 1.509/97, Rel. Desembargador Laerson Mauro, Rio de Janeiro, 05 de junho de 1997.

TJRJ, Apelação Cível n. 2007.001.06874, Rel. Desembargador Cláudio de Mello Tavares, Rio de Janeiro, 28 de março de 2007. 
TJRJ, Apelação Cível n. 2007.001.38311, Rel. Desembargador Mario Robert Mannheimer, Rio de Janeiro, 11 de setembro de 2007.

TJRJ, Apelação Cível nº 2007.001.48529, Rel. Desembargadora Kátia Torres, Rio de Janeiro, 16 de outubro de 2007.

TJRJ, Apelação Cível n ${ }^{0}$ 2007.001.64492, Rel. Desembargadora Denise Levy Tredler, Rio de Janeiro, 28 de janeiro de 2008. 